NBER WORKING PAPER SERIES

\title{
HEALTH, INFORMATION, AND MIGRATION: GEOGRAPHIC MOBILITY OF UNION ARMY VETERANS, 1860-1880
}

\author{
Chulhee Lee \\ Working Paper 11207 \\ http://www.nber.org/papers/w11207 \\ NATIONAL BUREAU OF ECONOMIC RESEARCH \\ 1050 Massachusetts Avenue \\ Cambridge, MA 02138 \\ March 2005
}

I thank Dora Costa, Joseph Ferrie, Clayne Pope, Richard Steckel, and the participants of the NBER Cohort Studies-Early Indicators Joint Conference in Salt Lake City (April 2004) for their helpful comments and suggestions, and Susan Jones for her editorial assistance. I gratefully acknowledge financial support from the National Institute on Aging, the National Institutes of Health (P01 AG10120). The views expressed herein are those of the author(s) and do not necessarily reflect the views of the National Bureau of Economic Research.

(C) 2005 by Chulhee Lee. All rights reserved. Short sections of text, not to exceed two paragraphs, may be quoted without explicit permission provided that full credit, including $($ ) notice, is given to the source. 
Health, Information, and Migration: Geographic Mobility of Union Army Veterans, 1860-1880

Chulhee Lee

NBER Working Paper No. 11207

March 2005

JEL No. J1, N3, I1

\begin{abstract}
This paper explores how injuries, sickness, and geographical mobility of Union Army veterans while in service affected their post-service migrations. Wartime wounds and illnesses significantly diminished the geographical mobility of veterans after the war. Geographic moves while carrying out military missions had strong positive effects on their post-service geographic mobility. Geographic moves while in service also influenced the choice of destination among the migrants. The farther into the South a veteran had traveled while in service, the higher the probability that he would migrate to the South. Furthermore, these migrants to the South were more likely to settle in a state they had entered while in service. Increased general knowledge about geographical transfer itself, greater information on distant lands and labor markets, and reduced psychological cost of moving were probably important mechanisms by which prior mobility affected subsequent migration. I discuss some implications of the results for the elements of self-selection in migration, the roles of different types of information in migration decisions, and the overall impact of the Civil War on geographic mobility.

Chulhee Lee

School of Economics

Seoul National University

Seoul, Korea

chullee@snu.ac.kr
\end{abstract}




\section{Introduction}

This paper explores how medical events and geographic mobility of Union Army veterans while in service affected their post-war migration. The main purpose of the present research is to understand the effects of health and information on migration decisions in nineteenth-century America. It is widely accepted that information is a key determinant of geographic mobility and location choice. Health is an important element of a person's human capital that can affect both the cost and benefit of migration. Only a few studies have explicitly investigated the effect of information on migration, and those have relied mostly on highly indirect measures of information, such as the extent of chain migration. Even less is known about the link between health and geographic mobility. To my knowledge, this study is the first to attempt to consider explicit measures of health and information together with other conventional variables on human capital attributes as determinants of migration.

The longitudinal data on Union Army veterans used in this study provide a unique opportunity to examine the effects of health and prior mobility on migration. Military service during the Civil War seriously damaged the health of a large number of recruits who survived the war. Since most battles were fought in either border or southern states, recruits from the North were deployed to distant regions along with their regiments, and thus gained opportunities to obtain first-hand knowledge about other locations. Wounds and illnesses suffered as well as geographic mobility while carrying out military missions were all unanticipated exogenous events, not related to the choice or characteristics of the recruits. By exploiting these special features of wartime experiences, I can mitigate potential problems of endogeneity and self-selection bias commonly confronted by previous studies on migration. Also, the data allow a rare opportunity to examine the association between health and mobility at relatively young ages thanks to the wide variations in wartime medical experiences.

My study will significantly deepen our understanding of the determinants of migration in several ways. First, it provides the very first rigorous evidence of how particular wounds and diseases influenced the probability of migration and the choice of 
destinations among migrants in the nineteenth-century United States, where geographic mobility was exceptionally high. It also offers fresh evidence regarding how prior mobility affected general geographic mobility and choice of destination. In addition, this paper gives new insights into the question of what kinds of information (e.g., information on passage, broad regions, and particular localities) mattered in making migration decisions, which has not been thoroughly explored.

This study is related to several other important issues in various fields, such as economic effects of Post Traumatic Stress Disorder (PTSD) and economic consequences of the Civil War. A large number of medical and epidemiological studies have investigated the persistent effect of wartime stress on health and mortality (Archibald and Tuddenham 1965, Beebe 1975, Berg and Richlin 1977, Dent et al. 1989, Goulston et al. 1985, Hearst, Newman, and Hulley 1986, Nefzger 1970, Lund et al. 1984, Smith et al. 1987, Spaulding 1977, Sutker et al. 1991, Ursano 1990). Also, there is a voluminous literature on the effect of veteran status on measures of economic performance (DeTray 1982, Berger and Hirsch 1983, Schwartz 1986 Angrist 1990). However, little is known about how the extent of wartime stress or particular wartime events affected later economic mobility. Lee (2003b, 2005) recently found that diseases, wounds, and combat exposure experienced by Union Army recruits while in service significantly diminished their wealth accumulation between 1860 and 1870. This study will add evidence on the impact of war service on geographic mobility to the literature.

Finally, this study will shed new light on our understanding of the economic costs of the Civil War. Whereas previous studies have mainly focused on the damage during the war itself (Goldin and Lewis 1975), my analysis of the Union Army data takes into account, in the estimation of human and physical losses, the persistent effects of military service on the economic mobility of Union Army veterans after the war. In a previous study, I suggested that the direct economic costs of the Civil War were probably much greater than previously thought if the persistent adverse effects of wartime experiences on veterans' health on wealth accumulation are considered (Lee 2005). The present study provides additional evidence on how the Civil War had an economic impact on individuals by affecting their geographic mobility. 


\section{Health, Information, and Mobility: Advantages of Using Military Data}

Throughout human history, migration has been a major form of investment by which people can improve their lifetime material (and sometimes nonmaterial) wellbeing. In the past, when access to formal education was limited to relatively few people, migration was perhaps a more important way of investing in human capital than it is today. It is now well established that geographic mobility in the United States during the nineteenth-century was exceptionally high by both historical and comparative standards (Ferrie 2004). The active inter-regional and rural-urban movement of the population seeking better opportunities is one of the main explanations for the high economic and social mobility observed in nineteenth-century America that gave it the reputation for being a "land of opportunity." It also contributed to the rapid growth of the U.S. economy by reallocating the labor force from low-wage to high-wage regions.

Naturally, one of the central issues among social scientists in various fields is why people migrate and how migrants choose their destinations. Studies viewing migration as a personal decision assume that migration is a type of investment that entails cost but produces a stream of return (Sjaastad 1962, Mincer 1978). A migrant contemplating migration from a given origin to given destinations compares the expected present value of lifetime income in his place of origin and the potential destinations, and chooses the place that maximizes his or her expected net benefit. According to this model of migration, the extent and pattern of geographic mobility are determined by the elements of the expected costs and benefits of migration. It has been established by previous studies that age, race, ethnicity, occupation, education, wealth, family structure, previous migration history, and labor market conditions of both the place of origin and potential destinations are important determinants of migration decisions (Bogue 1963, Steckel 1989, Galenson and Pope 1989, Margo 1990, Collins 1997, Hatton and Williamson 1998, Ferrie 1999). These finding are well matched to the investment approach to geographic mobility.

Health can affect geographical mobility in several ways. First, poor health increases the cost of relocation by curtailing one's physical capacity to move to and settle in a different location. Second, expectation of early death or early retirement arising from 
health problems will shorten the expected length of remaining work life, and thus diminish the anticipated net gain from the investment. Third, a decrease in productivity caused by bad health can reduce the economic gains from migration. Finally, severe disabilities or sickness may restrict one's occupational choice, or even labor force participation itself, consequently eliminating a potential path by which geographic mobility improves a migrant's economic status, namely, occupational mobility.

So far, there is no clear evidence supporting any of the possible mechanisms through which health can affect geographic mobility. Most studies on the relationship between health and migration focus on the adverse impacts of migration on health. It is well documented that geographic transfers usually had adverse effects on the health of migrants. Compared with natives, immigrants had higher mortality rates and poorer health conditions in nineteenth-century America (Higgs 1979, Fogel 1986). A study based on a longitudinal data found that migrants were at a much higher risk of dying of infectious diseases after they moved (Sánchez 2003). Migrants were often more vulnerable to infectious diseases in their new homes because they came in contact with a different disease pool against which they lacked immunities (McNeill 1976, Curtain 1989, Pritchett and Tunal1 1995, Lee 1997, 2003a). The rise in geographic mobility is largely accepted as a major cause of the deterioration in health, indicated by increased mortality and diminished adult height, in mid-nineteenth-century America (Steckel 1995). Physical and emotional stress in the course of long-distance relocation and resettlement, and frequent malnutrition, also damaged the health of migrants (Higgs 1979). In contrast to the abundant literature on the effect of migration on health, it is difficult to find evidence regarding how health influences geographic mobility. The absence of evidence seems to reflect the lack of appropriate data to be used to identify the previous health condition of the movers and non-movers.

Information plays a critical role when a migrant forms predictions about the costs and benefits of migration to a given place. For a risk-averse person, obtaining more information on regions outside the place of origin and general knowledge about moving itself (such as routes, transportation, cost, risks, and so on) may increase the probability of migration. Reliable information on the labor-market condition and living environment of a 
particular place could increase or decrease the probability of choosing it as the destination. The negative effect of distance on migration has often been suggested as evidence of the adverse effect of diminishing information on migration (Sjaastad 1962, Schwartz 1973). ${ }^{2}$ Lack of information about housing markets has been cited as a serious barrier for intraurban migration of blacks (Freeman and Sunshine 1976). The positive effect of education on the probability of migration of blacks out of the South in the late nineteenth and early twentieth centuries has been explained in part by the advantages more educated persons had in obtaining information on the labor markets in other regions (Margo 1990).

The prevalence of chain migration in many different times and places also indicates the importance of information as a determinant of mobility, especially in international migration. Numerous studies have found that the size of previous immigrants from a given country, province or community significantly increased the subsequent rate of immigration from the place (Murayama 1991, Wegge 1998, Hatton and Williamson 1998). This pattern of migration is largely explained by the effect of increased information flow as well as greater provisions of fixed costs of migration (such as remittance, prepaid tickets, and networked assistance upon arrival) from previous migrants. However, the size of migrant stock, even that of a narrowly defined community, is a highly indirect measure of information. It is unknown what fraction of the migrant-stock effect actually represents the effect of increased information rather than that of greater provision of support before departure or upon arrival. Nor is it clear what kind of information was particularly valuable for potential migrants. It might have been general information on a country or region as a whole that stimulated decisions to move. It is also possible that specific information on a particular locality or concerning passage to the destination was more helpful for potential migrants. Since most studies on chain migration do not say where the original and subsequent chain migrants moved to, it is difficult to identify which is the case.

Prior geographic mobility provides another measure of information about particular

\footnotetext{
${ }^{2}$ Increasing psychic cost with distance is another possible explanation for the negative relationship between distance and probability of migration. Schwartz (1973) found that aging (a proxy of the magnitude of psychic cost) did not affect the effect of distance on migration whereas increasing education (a proxy of more information) strongly diminished it, accepting the information hypothesis over the psychic cost hypothesis.
} 
locations a potential migrant possesses. A person who had visited a particular place should certainly possess more information about the location than someone who had not. Prior migration can also affect a person's mobility by changing his preferences (e.g., attitudes toward risk) or cognitive constructs. ${ }^{3}$ A series of studies by labor economists reported that prior migration, especially return migration, affected post-move job-searches and earnings by providing the movers with more information on the local labor market (Kau and Sirmans 1977, Farber 1978, DaVanzo 1983). ${ }^{4}$ Groen (2004) found that attending college in a given state modestly increased the probability of working in the state.

Prior mobility has some advantages as a more direct measure of information. If the specific destination of a migrant is known along with his prior mobility, it is possible to infer what kind of information he obtained from previous migration. For example, if prior migration only increased the probability of moving to the place previously visited, it is likely that the information on a specific locality matters for migration decisions. If prior migration increases general geographic mobility regardless of destination, or the probability of moving to nearby places, it implies that general information on a broad region or travel might be important. On the other hand, using prior mobility as a determinant of migration is subject to self-selection bias because past migration is by no means a random event. That is, individuals who had moved to a given place could differ from non-movers in terms of unobservable characteristics that influence mobility. ${ }^{5}$ Therefore, it is difficult to identify the pure effect of information on migration by looking at the influence of prior migration on individuals who could freely choose to move.

${ }^{3}$ According to the literature on behavioral geography, a person stores information on the real world as cognitive constructs through the filters of the perceptual senses and the value system, and they form the individual's cognitive environment. When the individual is choosing from among the possible locations in his environment for a place to migrate, he uses the information stored in those cognitive constructs rather than the objective information (Lloyd 1976).

${ }^{4}$ In contrast to claims that prior migration provides informational advantages, Herzog Jr., Hofler, and Schlottmann (1985) demonstrated that since first-time movers invested more heavily on information seeking activity, they had better information on wage distribution than that of repeat migrants.

5 The evidence of self-selection in migration is abundant. For example, see Wegge (1997) for nineteenth-century German immigrants and Herscivici (1998) for nineteenth-century internal migrants in the United States, and Robinson and Tomes (1982) for Canadian interprovincial migrants. 
The wartime experiences of Union Army veterans provide a unique opportunity to study the impacts of health on migration. Military service during the Civil War seriously damaged the health of recruits who survived the war. More than a quarter of the soldiers were injured, and two-thirds became ill at least once while in service. Military service records of the Civil War veterans linked to later censuses enable us to examine how the medical experiences of the recruits while in service affected their post-service geographic mobility. In particular, Union Army data allow a rare opportunity to examine the association between health and mobility at relatively young ages. Studies on health based on today's data are largely concerned with individuals at middle and older ages, in part because there are relatively small variations in health among the young. But due to the extremely varied wartime experiences of the recruits, we can observe substantial disparities in health at younger ages when geographic mobility is relatively high.

The studies on the impact of health on economic mobility are subject to several empirical difficulties. First, since current health is in part influenced by past socioeconomic status, and since socioeconomic conditions at different ages are to an extent correlated, there is a potential endogeneity problem. Second, in order to measure the pure health effect on mobility, it is desirable to see how unanticipated changes in health affect migration, because if people anticipate that their health will deteriorate, they may change their human capital investment behaviors. ${ }^{6}$ The Union Army data used in this study have some advantages over the modern datasets commonly used for studying the impact of health on economic status, such as the Health and Retirement Survey (HRS) and the Asset and Health Dynamics of the Oldest Old Survey (AHEAD), in dealing with this problem. First, in the mid-nineteenth century, there were few effective medical or health care services to be purchased. The most important link between economic status and health was the quality of nutrition and housing. There was less residential segregation by social class, and both the

\footnotetext{
${ }^{6}$ For this reason, some studies on the link between health and economic status use the onset of new chronic conditions as a predictor of savings. But, while new onsets may provide the best chance of identifying health shocks, not all new onsets come as a surprise. A number of studies have attempted to deal with this problem, employing various instruments. Ettner (1996) used the state unemployment rate, work experience, parental education, and spousal characteristics as instruments for an individuals' income. She found that the effect of income on health remains significant and even increases after instrumenting. Meer, Miller, and Rosen (2003) used the size of inheritance as an instrument for wealth. They found that the originally small but significant effect of wealth on health became statistically insignificant if instrumental variable estimation was applied.
} 
rich and the poor were exposed to a similar ecological environment. Furthermore, there was no medical insurance in the nineteenth century. Thus, we have fewer factors to mask the true effect of poor health on economic mobility in the past. ${ }^{7}$ Second, the military medical records enable us to isolate unanticipated changes in health. All recruits who passed the medical examination were presumably in relatively good health at the time of enlistment. Illnesses and injuries while in service were purely unanticipated events at enlistment. These features of the data provide an ideal setting in which we can analyze the influence of health on economic mobility.

In addition, the geographic scope of the military actions that took place during the Civil War provides an excellent opportunity to examine how prior mobility affects migration. Since most battles were fought either in border or southern states, many recruits from northern states were deployed to distant regions along with their regiments. The distance and pattern of transfers differed greatly from regiment to regiment. For example, recruits who enlisted in the Illinois $9^{\text {th }}$ Regiment were sent all the way down to the state of Mississippi via Kentucky and Tennessee. They also entered Georgia, South Carolina, North Carolina, Virginia, and Washington DC while carrying out their military missions. In contrast, recruits who served in the Delaware $9^{\text {th }}$ Regiment, organized in August 1864, never had a chance to move out of their state of origin. The unique nature of geographical movement while in military service, which is ideal for the purpose of my study, is that it was exogenously determined, completely unrelated to the recruit's decision. Since a recruit was normally enlisted in a regiment organized near where he lived along with other men from his community, he couldn't choose his military unit (Kemp 1990, Vinovskis 1990, Geary 1991). The enlisted men just went where their regiments were ordered to go. Thus, using wartime geographical mobility as a measure of information is not subject to the

\footnotetext{
7 The results of studies on the effects of socioeconomic status on health in the past are mixed. Steckel (1988) found that socioeconomic class differences in mortality among women and children in mid-nineteenth-century America were small based on a sample of families matched to the 1850 and 1860 censuses. Preston and Haines (1991) also reported that the influences of economic factors on child mortality at the end of the nineteenth century were relatively weak. Preston et al. (1981) suggested that the link between wealth and health became stronger over the twentieth century. In contrast, Ferrie (2003) found that socioeconomic status, especially wealth, was an important force shaping the mortality rates experienced by Americans in the middle of the nineteenth century, based on a sample of the mortality schedules of the 1850 and 1860 censuses. Lee (2003a) found that wealth had a significant positive effect on the health of Union Army recruits while in service.
} 
potential self-selection bias frequently confronted by studies examining the effect of prior mobility on migration decisions.

\section{Data}

This study is based on a sample of the several primary data sources that were collected and linked as part of the project titled "Early Indicators of Later Work Levels, Disease, and Death," jointly sponsored by the National Bureau of Economic Research, the National Institutes of Health, the Center for Population Economics at the University of Chicago, and Brigham Young University. The original population from which the sample used in this study was drawn is composed of 35,747 recruits who enlisted in 331 randomly selected Union Army companies. These recruits have been linked to various data sources, including military service records, pension records, and records from the 1850, 1860, 1900, and 1910 censuses. $^{8}$

The service records contain very detailed descriptions of the diseases or wounds that the recruits suffered during their military service. As soon as a recruit was too ill to report for duty, his condition was noted in morning reports. If his condition required medical attention, it was recorded in the regimental surgeon's report. If he was hospitalized, the diagnosis of the disease was described in the case history together with the ultimate outcome, such as return to service, discharge for disability, or death (U.S. Surgeon General's Office 1870, vol. 1). Information on disease and wounds, which was used in measuring the health of recruits, was gathered from these sources. Military service records also provide information on the demographic and socioeconomic characteristics of recruits prior to enlistment, including age, occupation, place of birth, height, and military career (rank, military duty, company, regiment, change in military status, dates of enlistment and discharge, and so on). Variables on occupation prior to military service, nativity, age, year of enlistment, and company death rates, which were used as either measures or

\footnotetext{
${ }^{8}$ See Fogel (1993, 2000a, 2000b, 2001) and Wimmer (2003) for more detailed explanations of the EI Project and data produced from the project. The data sets collected and linked as part of this project can be obtained from the web site of the Center for Population Economics (http://www.cpe.uchicago.edu).
} 
determinants of economic mobility or indexes of wartime stress, come from these records.

I also utilize an auxiliary data set, entitled Regimental History Records, that provides information on events in the histories of Union Army regiments. This data set was originally collected from The Compendium of the War of the Rebellion, compiled by Frederick Dyer (Dyer 1959). The types of military events contained in the source include "organized," "mustered in," "attached," detached," "moved to," "duty at or stationed at," "operations," "combat or combat preparation," and "discharged." The states where each event began and ended are identified, along with starting and ending dates and the number of men wounded or killed during the action. By matching this source to the Union Army sample based on the name of the regiment where the recruit served, I inferred which states each veteran entered while in service.

For the purpose of examining the patterns of geographical mobility after the Civil War, the recruits were located in, and linked to, the manuscript schedules of the 1880 population census. The search was restricted to 20,315 men who had not died until the 1880 census was enumerated (including those whose death dates are unknown) and for whom information on some basic characteristics such as birthplace and age at enlistment are given. As a result of the linkage process, 7,229 veterans (36\% of those who were searched) were successfully linked to the 1880 census. ${ }^{9}$ The sample is further restricted to 6,882 men who were aged 18 to 45 at enlistment and for whom the county of residence prior to military service is known.

Of these veterans, 3,144 are also linked to the 1860 census. Census records provide additional information on socioeconomic structure and on household structure prior to and shortly after the military service of recruits. They contain information on age, occupation, place of birth, personal and real estate wealth, place of residence, and literacy for other household members as well as the recruits. Among the variables required for this study, wealth and family structure prior to enlistment are found only in the 1860 census. Therefore, I limit the sample to the 1,097 recruits who were linked to both the 1860 and 1870 censuses whenever wealth or family structure is concerned.

\footnotetext{
${ }^{9}$ See Costa and Kahn (2003) for more detailed descriptions of the sample.
} 
Table 1 compares some key characteristics of recruits between the entire and selected samples. A comparison of the first and second columns of the table shows that the sample linked to the 1880 census is generally similar to the entire Union Army in terms of personal characteristics, and medical experiences and geographical movements while in service. The only notable difference is that in the linked sample, the native born (79\%) and farmers (53\%) are overrepresented compared to the recruits at large, of whom $69 \%$ were U.S. born and 49\% were farmers. For the smaller sample linked to both the 1860 and 1880 censuses, the percentages of the native born and farmers are even higher, $88 \%$ and $61 \%$, respectively (column 3 of Table 1). Also, a slightly larger fraction of the men found in both censuses suffered illnesses while in service. ${ }^{10}$ Even if we cannot preclude the possibility that the sample is subject to selection bias resulting from linkage failure, it is likely that the results of this study generally represent the experiences of the entire Union Army and perhaps the entire Northern male population at military service ages during the Civil War.

Table 2 provides the pattern of regional migration of the veterans in the sample. The states included in each region are listed in the Appendix. About two-thirds of the veterans remained in the same region they resided in at the time of enlistment. The rate of inter-regional migration was the highest for recruits from the West $(72 \%)$, followed by those from the border states (37\%). For the migrants from New England, the Mid Atlantic, East North Central, and West North Central regions were equally important regions of destination. The majority of migrants from the Mid-Atlantic headed to the Midwest, especially the West North Central region. A large fraction of the migrants from the East North Central region moved to the West North Central region. As in the case of the population at large, the geographical mobility of the veterans was characterized predominantly by East-West migration. Only $2 \%$ of the veterans had migrated to the South

${ }^{10}$ The overrepresentation of the U.S. born and higher disease rates among the recruits who were linked to the 1860 census can be explained in part by their higher linkage rate to pension records. Immigrants were less likely to be found in pension records because many foreigners who died during the early postwar years had no eligible dependents or were used behind the front and so were less likely to incur war-related disabilities (Fogel 1993). Army veterans with health problems originating from military service were more likely to apply for and receive pensions because early pension laws required such conditions. Therefore, it is not surprising that recruits who were linked to census records show more severe medical experiences while in service. 
by 1880 . Two-thirds of the migrants to the South settled in the West South Central region.

\section{Measuring Health and Information}

\section{Variables on Health}

Military service during the Civil War seriously damaged the health of recruits who survived the war. More than a quarter were injured, and two-thirds suffered various illnesses at least once while in service. Wartime illnesses were mainly caused by infectious diseases, although some chronic conditions such as rheumatism and hernia were also prevalent. Diarrhea was the most common disease in the army camp, contracted by a quarter of the recruits in the sample, followed by malaria $(16 \%)$, respiratory infections such as pneumonia and bronchitis (7\%), typhoid (6\%), and measles (4\%). The unusually high rates of disease contraction were due to the peculiar nature of the army camp, in which a large number of men from heterogeneous socioeconomic and ecological backgrounds were confined in an extremely unhealthy environment.

Many of the recruits who contracted infectious diseases while in service, if they survived, probably recovered from the illnesses rather quickly, even before they were discharged from their service. However, the damage caused by those acute diseases may have had persistent influences on their later health. Studies have found that infectious diseases affect the odds of suffering chronic conditions such as heart, respiratory, and musculoskeletal disorders at older ages (Elo and Preston 1992, Costa 2000). I use dummy variables indicating whether a veteran experienced a particular type of wound or disease as well as wounds and illnesses in general as a measure of health. The particular wartime events considered here include five types of wound by location and ten diseases that were most common among Union Army recruits: typhoid, smallpox, measles, diarrhea, respiratory infections, malaria, tuberculosis, rheumatism, syphilis, and hernia.

Illnesses and wounds are not the only kinds of health damage suffered by veterans who fought in a bloody war. The intense violence involved in war, such as being exposed to heavy combat, witnessing friends and comrades die, and watching the enemy before or after killing them, may have inflicted serious war trauma on the survivors. It has been 
reported that Post-Traumatic Stress Disorder (PTSD) was widespread and severe among the veterans who served in Vietnam and the Civil War (Dean, Jr. 1997). There is a large body of research linking war trauma with various mental and physical health outcomes. ${ }^{11}$

Since stress is not directly observable, it is necessary to develop an index to proxy the severity of wartime experiences. A company-level variable, such as the percentage of death from wounds in the recruit's company, is a good index of wartime stress since it incorporates several different aspects that contribute to stress. Residents of a town were often recruited to the same company, sent to the same battlegrounds, and fought side by side. Consequently, all individuals in a particular company were exposed to a similar level of stress. In particular, the company mortality from wounds provides a measure of common exposure to combat of recruits who served in the same company. ${ }^{12}$ The company mortality of Union Army recruits was closely linked to their post-service health status. Analyzing surgeons' physical examination data, Pizarro, Silver, and Prause (2004) recently found that a high company death rate significantly increased the probability of veterans' suffering various chronic cardiac, gastrointestinal, and nervous conditions when they were examined

${ }^{11}$ Epidemiologists studying PTSD in contemporary veterans reported that such wartime events as being wounded in combat, fired upon in combat, stationed in a combat zone, and being captured by the enemy had persistent and statistically significant effects on the later mortality and morbidity of veterans who fought in World War II, the Korean War, and the Vietnam War (Archibald and Tuddenham 1965, Beebe 1975, Berg and Richlin 1977a-d, Dent et al. 1989, Goulston et al. 1985, Hearst, Newman, and Hulley 1986, Nefzger 1970, Smith et al. 1987, Spaulding 1977, Sutker et al. 1991, Ursano 1990). Based on a sample of Union Army veterans, Costa (1993) found that imprisonment by the enemy, being wounded, and being discharged for injury or illness significantly increased the risk that veterans who survived to 1890 would die between the ages of 55 and 77 .

12 A typical company was composed of about one hundred men. In the entire Union Army sample, $23 \%$ of the recruits served in more than one company. For these recruits, the mortality of their first company was used to construct the wartime stress variables. The degree of wartime stress undergone by recruits, measured by the company mortality from wounds, greatly varied across different companies. Twenty-two percent of the recruits in the sample served in companies where not a single person was killed in action. In contrast, nearly $11 \%$ of the recruits fought in a company in which more than $10 \%$ of enlisted men died from wounds. Some recruits in the former category belonged to militia units formed exclusively from men of their locality and never saw battle. Many of them were recruited (and released) before the major battles or after Lee's surrender, and thus escaped not only the stress of combat but even a substantial threat of exposure to combat (Hamersly 1888). 
by surgeons to receive Union Army pensions. ${ }^{13}$ Lee $(2003 \mathrm{~b}, 2005)$ reported that the degree of combat exposure measured by the company mortality from wounds had a strong negative effect on the wealth accumulation of Union Army veterans between 1860 and 1870. Accordingly, I use dummy variables indicating four levels of company mortality from wounds, (1) zero (2) $3 \%$ or less (3) $3 \%$ to $5 \%$, and (4) more than $5 \%$ (denoted as Co wound mortality 1 through 4 ) as an index of wartime stress.

In addition to the variables on wartime experiences, I add variables on height at the time of enlistment as an indicator of the nutritional status of recruits. Since it is inappropriate to compare the height of a recruit at a growing age with one who had already reached his final stature, it is desirable to use an age-standardized measure of height. Accordingly, I construct five dummy variables on height (Height 1 to Height 5), each of which represents a quintile of the height distribution for a particular age. For age 18, for example, recruits with heights from 64.5 inches to 67 inches were classified as the fourth quintile; for age 19, recruits whose heights were 65 inches to 66.25 inches were included in the same category. The height distribution by age was obtained from the entire Union Army sample. A single height distribution was applied to all recruits 23 and older, based on the assumption that height after age 23 remained unchanged.

\section{Measuring Wartime Geographical Mobility}

I use several different measures of geographical mobility while in service, each of which represents a particular type of information. First, I consider how far the veteran moved from his place of origin while in service. The underlying rationale for using the measure is that distance traveled can influence the mover's cognition of other places, general knowledge about the passage, attitudes toward risk, and preference for relocation.

\footnotetext{
${ }^{13}$ Lee (2005) also reported that the company mortality was positively related to the proportion of veterans who had received pensions by 1890 and the average amount of pension given to the recipients in 1890. Given that the very sick got into the pension rolls earlier and received a larger pension, this indicates that the veterans who served in a company that lost a large fraction of servicemen during the war were less healthy than those who fought in a low-mortality company. In addition, the company mortality from wounds had a weak positive relationship to post-service mortality.
} 
The information obtained from prior mobility may differ between latitudinal (East-West) and longitudinal (North-South) moves. Steckel (1983) noted that an important basis of the dominant pattern of East-West migrations in nineteenth-century America was the desire of the migrants to relocate to areas where their agricultural knowledge of the climate and soil type would still be applicable. It is likely, therefore, that the veterans who moved longitudinally were exposed to a greater variety of unfamiliar environments than those who traveled the same distance horizontally. Also, the veterans may have collected different kinds of information from their military movements depending on the direction. To consider these potential differences, I use separate variables on both longitudinal and latitudinal moves in the analysis (denoted "North-South move" and "East-West move" in the tables reporting the results of regression analyses), representing the distance from the county of residence at enlistment and the longitudinally (horizontally) most remote state the veteran had ever entered while in service. ${ }^{14}$

The second measure of wartime geographic mobility is the distance (measured in the unit of longitudinal degrees) a given recruit moved below latitude $40^{\circ}$ north (denoted "latitudes moved below 40 degrees" in the table reporting the regression results). This measure represents how far a person entered into the South during his service. The most peculiar feature of the military deployment during the Civil War is that it was predominantly south-bound. The vast majority of the recruits moved to the border states such as Virginia and Maryland. More than half of the Union Army entered either the South Atlantic or the East South Central region, and nearly a quarter of them marched into the West South Central region. A natural question arising from this pattern of wartime mobility is how wartime experiences of visiting the South affected northern veterans' later migration to the region. I assume that the lowest latitude reached by a given soldier represents the extent of his exposure to the environments and labor-market conditions in the South.

Finally, dummy variables indicating whether a veteran had ever entered a particular

14 This measure represents the difference in the latitude (longitude) between the county of residence at enlistment and the most distant state horizontally (longitudinally) from the place of origin. The regimental history records usually do not provide the names of the county or town where the given military action took place. Accordingly, I use the distance between the county of enlistment and the capitol of the state the given recruit entered in measuring the mobility while in service. 
region in the South (such as the South Atlantic, the East South Central, and the West South Central) are used as measures of the information on broadly-defined regions. These variables will be employed in analyzing the determinants of the general mobility and the probability of choosing the South as the destination among the movers. In addition, dummy variables of entering particular states are used in examining how location-specific information affected the choice of state among the migrants to the South.

\section{Health, Wartime Mobility, and Migration}

Migration may be modeled as a type of investment in human capital to increase the present value of life-time earnings. A soldier discharged from military service would have faced a choice between remaining in his previous place of residence and moving to another place. Moving to a different place can bring a rise in life-time income or social status, but at the same time, incurs a cost of relocation. The chances that a person will switch location will depend on the net income gains, discounted by his rate of time preference, over his remaining work life (Ferrie 1999).

Some possible paths through which health and information can affect geographical mobility were suggested above (see Section 2). In addition to health and information, geographical mobility can be determined by other human capital attributes, such as age, nativity, and literacy. Older age is associated with a shorter remaining work life and greater psychological cost of relocation. Therefore, the impact of age on mobility among adults is likely to be negative. Immigrants may have been more mobile because they had less strong connections to the community where they resided at the time of enlistment. Illiterate persons should have been at a disadvantage in obtaining information required for migration decisions. In addition to these variables pertaining to human capital, dummy variables on the region of enlistment were included to account for the possibility that geographic mobility was influenced by the conditions of the local labor market.

A problem with comparing the places of residence at enlistment and in 1880 is that the length of the period at risk of migration differs between veterans, depending on their year of enlistment. For veterans who enlisted in 1861, for example, we observe geographic 
mobility for 19 years; for those who entered the army in 1865, on the other hand, we observe mobility for only 15 years. To account for the difference in the length of the period at risk, I add dummy variables on the year of enlistment.

The measured rates of migration will depend heavily on the size of the geographic units used. The larger the geographic unit employed, the lower the rate of migration across the units. Accordingly, I employ four different measures of geographic mobility and corresponding specifications for regressions: (1) the distance of migration measured in miles, (2) the probability of moving to a different county, (3) the probability of moving to a different state, and (4) the probability of moving to a different region.

Table 3 presents the results of baseline logistic regressions. They suggest that wounds and illnesses experienced while in service had significant negative effects on the measures of geographical mobility. The size of the impacts of wartime medical experiences on the probabilities of migration was large. Suffering any wounds while in service reduced the probability of moving to a different county by $20 \%$. Any type of wartime illnesses diminished the probability of inter-county migration by $24 \%$. Wounds and illnesses in general also had modest but significant effects on the distance of migration, diminishing it by, respectively, 34 miles and 54 miles, or $8 \%$ and $12 \%$ of the sample average distance of migration (448 miles).

Wartime wounds and illnesses affected different aspects of geographical mobility. Contracting any disease while in service had a strong negative effect on the distance of migration among migrants as well as the probability of leaving the place of origin. It diminished the probability of inter-state migration by $20 \%$ and the chances of inter-regional migration by $17 \%$. The results of regressions conducted exclusively for the movers to a different county (not reported here) suggest that wartime illnesses decreased the distance of migration by 43 miles, which is not much different from the result for the entire sample. This indicates that the observed negative effect of having suffered illness on the distance of migration largely reflects its impact on the distance conditional on moving, rather than the probability of migration. In contrast, wartime wounds mostly affected the veteran's decision whether or not to move, rather than how far he would move. Wounds incurred while in 
service did not significantly decrease the probabilities of inter-state and inter-regional migrations. Among movers, moreover, it diminished the distance of migration by only 17 miles.

The company mortality from wounds, a measure of the extent of combat exposure, did not have any significant effect on geographic mobility. This result is in contrast to the result that Union Army veterans who fought in high-mortality companies saved much less than those who served in low-mortality companies (Lee 2005). This may indicate that geographic mobility is determined mainly by physical health, not mental health, which could have been more seriously damaged by trauma from bloody battles. It is also possible that psychological trauma made it difficult for the veteran to remain in his original community, offsetting the potential impacts of poor health caused by combat exposure. Height, another measure of health, had no systematic effect on geographic mobility, either.

Wartime geographical movements had significant effects on some measures of post-service geographic mobility. The measure of North-South moves significantly increased the probability of inter-regional migration and the distance of migration. On the other hand, the measure of East-West moves is positively related to the probabilities of moving to a different county and moving to a different state. The magnitudes of the effects were substantial. For instance, entering a state located in the South of the place of enlistment by seven degrees of latitude (the sample average of the latitudes moved) was associated with an increase in the probability of inter-regional migration by $27 \%$ and an increase in the distance of migration by 45 miles. Similarly, visiting a state that is horizontally distant from the place of origin by the sample mean (7.4 degrees) increased the probabilities of inter-county and inter-state migrations by $26 \%$ and $25 \%$, respectively.

The effect of wartime mobility on subsequent migration depended on whether the move was horizontal or longitudinal. North-South movements in the army largely affected the distance of migration among movers. It did not have any significant effect on the probability of relatively short-range migrations, such as inter-county and inter-state migrations. If the regression analysis is limited to migrants to a different county, the size of the effect of the latitudes moved is even bigger ( 7.8 miles, compared to 6.4 miles for the 
full sample). On the other hand, latitudinal mobility while in service affected the probability of migration, not the distance. This pattern could be explained by the fact that veterans who moved longitudinally were probably more likely to be exposed to an environment much different from their place of origin than those who traveled the same distance horizontally. Therefore, longitudinal mobility during military service should have provided more useful information for long-distance migration.

Among other variables included in the regressions, immigrant status stands out as the most powerful determinant of geographical mobility. Natives were much less mobile than immigrants by all four measures of mobility. Age is negatively related to geographical mobility, as found in other studies on the determinants of migration, but its effect is statistically insignificant for all four measures of mobility. The veterans whose occupations at enlistment were unknown were more mobile than those whose occupation was reported. Managers and proprietors, and unskilled workers moved farther on average than did farmers and professionals. The effect of the year of enlistment on mobility depended on the measure of mobility chosen. In general, the veterans who entered the army in either 1862 or 1864 were less mobile than the others. Finally, the veterans from the West were much more likely to migrate, and move a longer distance than the rest. The enlistees from the North West Central region were more mobile than those from the Northeast, although they were less likely to move out of the region. ${ }^{15}$

Table 4 reports the results of regressions employing more detailed classifications of wounds and illnesses. Regression coefficients for all other control variables are excluded

15 Previous studies have found that wealth, household structure, and literacy are significant predictors of geographic mobility (Galenson and Pope 1989). To consider the effects of these variables on migration, I conducted regressions in which these variables were added to the original set of variables reported in Table 3, based on a sample of 2744 men linked to the 1860 census. According to the results, presented in Appendix Table, real estate wealth was negatively related to the measures of geographic mobility, but its effect was statistically insignificant. On the other hand, personal wealth had a significant positive effect on the probability of migration. Illiterate veterans were significantly less likely to move to a different region. The effects of the variables on family structure are not significant in general, but presence of children increased the probability of interregional migration. The effects of wartime experiences, especially illnesses and East-West moves while in service, on migration are much weaker in these regressions than the regressions based on the full sample. The differences are mainly due to the selection of the sample, not the inclusion of variables on wealth, illiteracy, and family structure. 
from the table but included in the regressions. The results for these variables are similar to the results reported in Table 3. Among wounds on various body parts, injuries to a leg or foot had the most powerful negative effect on geographical mobility, although it is statistically significant only for the probabilities of inter-county and inter-state migrations. The majority of specific diseases had negative effects on geographic mobility but many of them miss statistical significance. Measles strongly diminished the distance of migration, and diarrhea and malaria exerted particularly powerful negative effects on the probability of inter-county migration. The probability of inter-regional mobility was most strongly affected by tuberculosis.

Table 5 presents the results of regressions employing three different sets of measures of wartime geographical mobility, namely, (1) latitudes and longitudes moved, excluding the interaction term, (2) dummy variables on entering three southern regions while in service, and (3) variables on regions entered and the distance of the move combined. Dropping the term of interaction between horizontal and longitudinal moves decreased the size of coefficients, but the implications of the results are generally similar to those reported in Table 3. That is, latitudinal moves largely increased the probability of migration, whereas longitudinal moves mostly increased the distance of migration. The results of the regressions that include the regions entered while in service suggest that having been to the West South Central region during the war greatly stimulated migrations of the veterans after the war. Even if the latitudes and longitudes moved are controlled for, the strong effect of entering the West South Central region does not disappear, although its effect on the distance of migration misses statistical significance by a small margin. When the regions entered are considered, the effect of latitudes moved on the distance of migration and the probability of regional migration becomes more powerful. ${ }^{16}$

Table 6 presents summary results of the regressions performed separately for

\footnotetext{
${ }^{16}$ Another interesting result from the change in specification is that East-West moves now have a very strong effect on the distance of migration and the probability of regional migration as well as the probability of inter-state migration. This result may reflect the fact that many recruits who moved from the Northeast to the East South Central region moved the longest distance to the West while in service, and they were less likely to move into the West South Central region.
} 
several sub-samples of the veterans with different ages, occupations, and nativities. The relationship between their wartime experiences and the measures of geographic mobility varied considerably between veterans with different human capital attributes. In general, the impacts on migration of medical events and geographic moves while in service were significantly weaker for younger men, white-collar workers, and immigrants than for older persons, manual workers, and natives, respectively. In particular, it is notable that wartime geographic moves had no significant effect on the migration decisions of the veterans aged 30 or older. It is also striking that the post-service geographic mobility of white-collar workers was not significantly influenced by wartime diseases, and was negatively related to geographic mobility while in service.

The variations across individuals with different characteristics offer useful clues to the question of why wartime events affected subsequent geographic mobility. The effect of wartime illnesses on mobility was stronger for the veterans employed in occupations that required greater physical strength (artisans and manual laborers) than for those engaged in jobs for which non-physical human capital was more important (professionals, managers, and proprietors). If poor health restricted mobility by limiting the person's ability to move, its effect should not differ by personal characteristics. Thus, the major link between wartime illnesses and geographic mobility was probably the decline in the benefits of migration caused by either the expectation of early retirement or by diminished physical ability.

If wartime geographic mobility increased the probability of migration by offering more general knowledge about moving itself or by mitigating the psychological cost of relocation, veterans with more prior experience of migration should have been less affected by the military experiences. The results reported in Table 6 suggest that geographic moves while in service had much weaker effects on the mobility of older persons and immigrants than, respectively, younger recruits and natives. Since older men and immigrants presumably had more prior experience of moving compared to the young and natives, the results indicate that the increased general information on geographical transfers and reduced psychological resistance to moving to a new location were indeed important 
mechanisms by which prior mobility affected subsequent migration.

Wartime mobility, especially longitudinal moves, had a particularly powerful positive effect on the geographic mobility of farmers. The mobility of the unskilled was strongly influenced by latitudinal moves while in service. In contrast, wartime mobility decreased the post-war mobility of white-collar workers. These results suggest that new information on climate and lands in other regions collected while serving in the army could be one of the possible links between the wartime mobility and post-war migration, especially for farmers. The general information on labor market conditions in other regions obtained in the course of military deployment might be another connecting factor, especially for less-skilled workers, as indicated by the strong relationship between latitudinal moves while in service and the probability of migration among the unskilled. A white-collar worker's human capital should be more heterogenous and location-specific than a manual worker's. Therefore, the information on distant labor markets collected during the war should have been too general and incomplete to influence a white-collar worker's migration.

\section{Location-Specific Information and Choice of the Destination}

The results given above suggest that wartime geographic mobility increased the probability and distance of migration of the recruits after the service. I will examine below whether the information on a particular place obtained while carrying out military missions indeed increased the probability of moving to that place. As noted above, the geographic moves of Union Army soldiers while in service were predominantly south-bound. Given this peculiar feature of the military deployment, I focus on the patterns of migration to the South to examine how location-specific information influenced the choice of the destination among the migrants. More specifically, I attempt to answer below the following two questions: (1) How did geographic mobility while in service affect the probability of choosing the South as the destination among the inter-state migrants? (2) Did prior experience of entering a particular state while in service increase the probability of moving to the state among the migrants to the South? 


\section{Region-Specific Information and Migration to the South}

The Union Army recruits who were sent to the South on military missions should have collected some knowledge about the region as a whole, such as its climate, terrain, soil, and socioeconomic conditions. Many of them were presumably strangers to the region. Therefore, veterans' impressions of the South and the information they acquired about it should have varied considerably depending on their wartime experiences. A natural question arising from this unique aspect of the Civil War is how such different regionspecific information affected the veteran's decision to migrate to the South.

As a measure of the region-specific information, I consider how far a given veteran entered into the South while in service, represented by the difference between latitude $40^{\circ}$ north and the lowest latitude he had ever reached. The underlying assumption is that the lowest latitude reached by the veteran represents the extent of his exposure to the environments and labor-market conditions in the South. The regression analysis is limited to the veterans who enlisted in the North, excluding those from the West and the border states, who migrated to a different region by 1880 . The following three types of migration to the South were separately considered in the regressions: (1) moving to the South including the border states, (2) moving to the South excluding the border states, and (3) moving to the border states.

Table 7 presents the results of logit regressions. They suggest that the deeper a veteran had moved into the South while in service, the higher the probability that he would migrate to the South. However, the measure of prior mobility to the South had no significant effect on the conditional probability of moving to the border states. The magnitude of the effect of wartime mobility is quite large. A south-bound move by one degree of latitude was associated with an increase in the probability of choosing the South (excluding the border states) as the destination by $11.3 \%$. This implies that wartime movement to the South by the sample mean (6 degrees) would have increased the conditional probability of migration to the South by $68 \%$. I also performed regressions including the dummy variables indicating which regions in the South a given veteran had 
entered while in service. The results, not reported here, suggest that having been to the South Atlantic and the West South Central regions while in service increased the probability of moving to the South by more than $75 \%$ for the entire sample. For the sub-sample of inter-regional migrants, entering these two regions while in service increased the probability of choosing the South as the destination by $50 \%$ and $80 \%$, respectively.

It is also notable that suffering illnesses while in service strongly reduced the conditional probability of moving to the South. It was reported above that illnesses in general restricted long-distance migration of the veterans (see Table 3). Poor health could have been an even more serious obstacle to migration to the South than moving to other regions owing to the relatively severe disease environment in the South. In contrast, wartime wounds had no significant effect on the conditional probability of moving to the South. The migrants from the North West Central region were much more likely to choose the South as their destination, probably due to the fact that the West South Central region was the most attractive location to the migrants within the South and it is geographically close to the North West Central region. ${ }^{17}$

\section{State-Specific Information and Choice of State: Conditional Logit Analysis}

The results given above suggest that region-specific information did matter for the migrants when choosing the destination. Now, I go one step further to examine whether possessing information on a particular state affected the probability of choosing that state among the migrants to the South. A veteran who had decided to migrate to the South had fourteen choices for his destination (the number of the states and district in the South to which at least one veteran from the North chose to move). To analyze how prior experience of visiting a particular state affected the veteran's choice, I employ the following conditional logit model. In this model, the probability that veteran $i$ moved to state $j$ is

\footnotetext{
${ }^{17}$ Of the veterans in the sample, $1.4 \%$ moved to the West South Central region, much greater than the $0.3 \%$ who moved to the South Atlantic or the $0.4 \%$ who moved to the East South Central region. Also, 3.3\% of the men from the North West Central region migrated to the West South Central, whereas only $1.1 \%$ of men from the other regions in the North moved there.
} 


$$
\operatorname{Pr}\left[S_{i j}=1\right]=\frac{\exp \left(\alpha x_{i j}+\beta^{\prime} Z_{i j}\right)}{\sum_{j} \exp \left(\alpha x_{i j}+\beta^{\prime} Z_{i j}\right)}
$$

where $x_{i j}$ stands for a dummy variable that has value of one if the veteran $i$ had ever entered state $j$ while in service, and $Z_{i j}$ denotes a vector of other determining factors of location choice. The conditional logit model has some advantages: the predicted probabilities are bounded between 0 and 1 , and the probabilities add up to 1 over states for a given individual. More importantly, the conditional logit recognizes the grouped nature of the data, with 14 observations for each veteran.

As other determining factors of the probability of choosing state $j$ (elements of $Z_{i j}$ ), variables on the longitudinal and latitudinal distances between the veteran $i$ 's state of origin of and state $j$, and the increase in the adult population in state $j$ between 1860 and 1880, are included. ${ }^{18}$ Other things being equal, a person would be less likely to choose a more distant state over a neighboring state. It is therefore expected that the coefficients on the distance variables have negative signs. The increase in the adult population is a proxy for the general attractiveness of the state for potential migrants. It is anticipated that, other conditions being equal, the veterans were more likely to choose a state with a larger population growth.

Table 8 presents the results of conditional logit regressions based on the model presented above. The second column reports the result of the regression in which variables on personal characteristics and wartime medical experiences (the same set of variables included in Table 3) are controlled for. The results strongly suggest that, holding the longitudinal and latitudinal distances and the population growth constant, the migrants to the South were more likely to settle in a state they had entered while in service. The estimated coefficient shows that a prior visit to a particular state increased the conditional probability of choosing that state as the destination by $38 \%$. As expected, the longitudinal and latitudinal distances are negatively related to the probability of choosing the state. Also, the migrants to the South were more likely to choose the state that had experienced a larger

18 The increase in the population in each state between 1860 and 1880 was calculated from U.S. Bureau of the Census (1970), A195-209. 
population growth. Including the variables on personal characteristics and wartime medical experiences do not change the results significantly.

\section{Conclusions and Further Implications}

This paper has explored how injuries, sickness, and geographical mobility of Union Army veterans while in service affected their post-service migrations. It is the first attempt to consider explicit measures of health and information together with other conventional variables on human capital attributes as determinants of migration. The results suggest that wartime wounds and illnesses significantly diminished veterans' geographical mobility after the war. Illnesses while in service had a particularly strong negative effect on the distance of migration among migrants. On the other hand, wartime wounds mostly decreased the probability, not the distance, of migration.

Veterans' wartime geographic moves had significant positive effects on their postservice geographic mobility. The effect of wartime mobility on subsequent migration depended on whether it was a latitudinal or longitudinal move. The distance of longitudinal (North-South) mobility significantly increased the probability of inter-regional migration and the distance of migration. On the other hand, the distance of a latitudinal (East-West) move was positively related to the probabilities of moving to a different county and moving to a different state. That is, North-South movements in the army largely affected the distance of migration among movers, whereas latitudinal mobility increased the probability of migration, not the distance. The relationship between wartime experiences and the measures of geographic mobility varied considerably across groups with different human capital attributes. In general, the effects of medical events and geographic moves while in service on migration were significantly weaker for younger men, white-collar workers, and immigrants than for older persons, manual workers, and natives, respectively.

Geographic moves while in service also influenced the choice of the destination among the migrants. The deeper a veteran had moved into the South while in service, the higher the probability that he would migrate there. Furthermore, the results of conditional logit analyses suggest that the migrants to the South were more likely to settle in a state 
they had entered while in service, when other determinants of the choice of state, such as the distance and population growth, are controlled for.

The results of this study provide the first direct evidence suggesting that health was a powerful determinant of geographic mobility in the nineteenth century. Given that the infectious diseases considered in the present study were widespread among the civilian population until the end of the nineteenth century, it is likely that the strong negative relationship between illnesses and geographic mobility found for the army recruits was true for the population at large, too. There is increasing evidence that economic costs arising from poor health are substantial (Deolaliker 1998, Behrman and Deolaliker 1989, Strauss and Thomas 1992, Smith 1999, Lee 2005). The high prevalence of various infectious diseases in the past should have adversely affected the economic mobility of the infected people by limiting their geographical mobility. The decline in the influence of infectious diseases since the late nineteenth century, therefore, should have exerted a favorable effect on overall geographic mobility.

The results regarding the link between health and mobility also have a significant implication for the issue of self selection in migration decisions. Though it is largely acknowledged that migrants are probably different from non-movers, even from those who have similar observable characteristics, it is not clear what the unobservable differences between them truly are. The evidence given here suggests that health differences could be one of the important elements of self-selection in migrations. That is, migrants are more productive than non-movers with similar personal characteristics thanks partly to their superior health. In addition, health could influence other unobservable determinants of geographical mobility, such as the psychological cost of relocation and attitudes towards risk.

This paper offers new evidence on the effect of information on geographic mobility by examining how exogenously determined prior mobility affected subsequent migration decisions. In addition, unlike other studies, mine distinguishes between the effects of different types of information, namely, (1) general knowledge on moving itself obtained from prior geographic moves, (2) region-specific (or latitude-specific) information gained 
from entering a particular region, and (3) state-specific information collected while visiting a particular state. The results suggest that all types of information mattered in migration decisions, but in different ways. ${ }^{19}$

This study also provides insights as to how prior mobility affects subsequent migration. The major link between wartime illnesses and geographic mobility was probably the decline in the benefits of migration caused by either the expectation of early retirement or by diminished physical ability. Increased general knowledge about geographical transfer itself, greater information on distant lands and labor markets, and reduced psychological cost of moving were probably important mechanisms by which prior mobility affected subsequent migration.

The results of this paper imply that a geographic move, regardless of its purpose, can stimulate subsequent mobility, not only to the place of visit but also to other locations. Visiting a new place will provide the visitor with some information about the location even if there is no intention of permanent relocation with the visit. Some examples of such events include sending of troops to a foreign country, transfers of workers to a distant branch, and relocations of refuges forced by political or economic disasters. Tourism and foreign studies, though not completely exogenous events, may encourage permanent migrants, too.

Finally, this study suggests that the Civil War had mixed effects on the geographic

${ }^{19}$ First, the extent of prior geographical mobility (measured by the distance to the most remote state from the place of origin) strongly increased the probability that a given individual moved to a different place, regardless of the destination. This is perhaps due to increased general information on relocation such as the knowledge about passage itself. Prior mobility may have changed a person's attitudes toward moving to a new place. It is notable that longitudinal and latitudinal moves had different effects on migration, presumably because the information offered by prior mobility differed depending on its direction. Secondly, the region-specific information (obtained from entering deep into the South while in service) increased the probability that the migrants chose a particular region (the South in this case) as the destination. Lastly, the statespecific information (collected by entering a particular state in the South) significantly increased the conditional probability that the migrants to the South chose a particular state within the region. These results suggest that information on a particular location plays an important role when choosing the destination. 
mobility of Union Army veterans. It reduced the probability of migration by damaging their health. On the other hand, it stimulated their geographic mobility by sending them to distant regions. Given that the measures of health and wartime geographic mobility are by no means complete, and the estimated magnitudes of their effects on geographical mobility are not fully accurate, it is difficult to determine which impact of the war was stronger. However, the regression results and the aggregate migration rates of the veterans suggest that the overall net effect of the war on the recruits' geographical mobility was probably positive. First, by multiplying the sample means and the regression coefficients of the variables on wounds, illnesses, and wartime mobility, I calculated the size of the effect that each of the wartime experiences had on geographical mobility. ${ }^{20}$ The results of the computations generally suggest that the positive effect of wartime mobility was strong enough to dominate the negative effect of wartime medical events. ${ }^{21}$ Second, the migration rates of the native-born veterans aged 25 to 45 were higher than the migration rates for the ransom sample of native-born males at the same age between 1860 and 1880 reported in Ferrie (2004). The inter-county and inter-state migration rates were respectively $77 \%$ and $42 \%$ for the veterans, whereas they were respectively $58 \%$ and $37 \%$ for the random sample.

\section{REFERENCES}

Angrist, J. 1990. "Lifetime Earnings and the Vietnam Era Draft Lottery: Evidence from Social Security Administrative Records," American Economic Review 80, 313-336.

Archibald H. C., and Tuddenham, R. D. 1965. "Persistent Stress: Reaction after Combat," Archives of General Psychiatry 12, 475-81.

Beebe, Gilbert W. 1975. "Follow-up Studies of World War II and Korean War Prisoners, II: Morbidity, Disability, and Maladjustments," American Journal of Epidemiology 101, 400-422.

\footnotetext{
${ }^{20}$ For instance, the effect of wounds on the aggregate inter-county migration rate can be calculated by multiplying the proportion of the veterans wounded $(0.269)$ by the size of its effect on the probability of moving to a different county $(-0.202)$. According to this calculation, wartime wounds decreased the rate of migration by $5.4 \%$.

${ }^{21}$ For instance, the net effect of wartime experiences was an increase in the probability of intercounty migration by $11.3 \%$ and the probability of inter-regional migration by $34 \%$ only if the statistically significant coefficients were counted. Even if all estimated coefficients are considered, the general implications remain unchanged, except that the net effect of the military events on the probability of inter-county migration switches to negative.
} 
Behrman J. R., and A. B. Deolaliker. 1989. "Agricultural Wages in India: The Role of Health, Nutrition, and Seasonality," In D. Sahn, ed., Seasonal Variability in Third World Agriculture. Baltimore: Johns Hopkins University Press, 107-17.

Berg, S. William and Milton Richlin. 1977a. "Injuries and Illnesses of Vietnam War POWs, I. Navy POWs," Military Medicine 143, Jul., 514-517.

Berg, S. William and Milton Richlin. 1977b. "Injuries and Illnesses of Vietnam War POWs, II. Army POWs," Military Medicine 143, Aug., 598-602.

Berg, S. William and Milton Richlin. 1977c. "Injuries and Illnesses of Vietnam War POWs, III. Marine Corps POWs," Military Medicine 143, Sept., 678-679.

Berg, S. William and Milton Richlin. 1977d. "Injuries and Illnesses of Vietnam War POWs, IV. Comparison of Captivity Effects in North and South Vietnam," Military Medicine 143, Oct., 757761.

Bogue, Alan G. 1963. From Prairie to Cornbelt: Farming on the Illinois and Iowa Prairies in the Nineteenth Century, University of Chicago Press.

Collins, W. J. 1997. "When the Tide Turned: Immigration and the Delay of the Great Black Migration," Journal of Economic History 57, 607-632.

Costa D. L. 1993. "Health, Weight, Wartime Stress, and Older Age Mortality: Evidence from Union Army Records," Explorations in Economic History 30, 424-49. 1998. Evolution of Retirement, Chicago: University of Chicago Press. 2000. "Understanding the Twentieth-Century Decline in Chronic Conditions among Older Men," Demography 37, 53-72.

Costa, D. L., and M. Kahn. 2003. "Cowards and Heroes: Group Loyalty in the American Civil War," Quarterly Journal of Economics 118, 519-548.

Curtin, P. D. 1989. Death by Migration, Cambridge: Cambridge University Press.

DaVanzo, Julie. 1983. "Repeat Migration in the United States: Who Moves Back and Who Moves On?" Review of Economics and Statistics 65, 552-559.

Dent, Owen F., B. Richardson, S. Wilson, K. Goulston and C. Murdoch. 1989. "Postwar Mortality among Australian World War II Prisoners of the Japanese," Medical Journal of Australia 150, 378382.

Dean, E. C., Jr. 1997. Shook over Hell: Post-Traumatic Stress, Vietnam, and the Civil War, Cambridge: Harvard University Press.

Deolaliker, A. B. 1988. "Do Health and Nutrition Influence Labor Productivity in Agriculture? Econometric Estimates for Rural India," Review of Economics and Statistics 70, 406-413.

Dyer, Frederick H. 1959. A Compendium of the War of the Rebellion, Vol. 1, New York: Thomas 
Yoseloff.

Elo, I. T., and S. H. Preston. 1992. "Effects of Early-Life Conditions on Adult Mortality: A Review," Population Index 58, 186-212.

Ettner, S. 1996. "New Evidence on the Relationship between Income and Health," Journal of Health Economics 15, 67-85.

Farber, Stephen C. 1978. “A Directional Flow Migration Model,” Southern Economic Journal 45, 205-217.

Ferrie, J. P. 1999. Yankeys Now, New York: Oxford University Press. . 2003. "The rich and the dead: Socioeconomic status and mortality in the United States, 1850-1860," in D. Costa, ed., Health and labor force participation over the life cycle, Chicago: University of Chicago Press, 11-50.

. 2004. The End of American Exceptionalism: Occupational and Geographic Mobility in the U.S., 1850-2000, mimeo, Department of Economics, Northwestern University.

Figley C. R. 1977. "Symptoms of Delayed Combat Stress among a College Sample of Vietnam Veterans," Military Medicine 143, 107-10.

Fogel RW. 1986. "Nutrition and the Decline in Mortality since 1700: Some Additional Preliminary Findings." In S. Engerman, and R. Gallman, eds., Long-Term Factors in American Economic Growth, Chicago: Chicago Univ. Press.

Fogel R. W. 1993. "New Sources and New Techniques for the Study of Secular Trends in Nutritional Status, Health, and Mortality, and the Process of Aging," Historical Methods 26, 5-44. . 2000a. Public Use Tape on the Aging of the Veterans of the Union Army Data User's

Manual: Military, Pension, and Medical Records 1820-1940, Version M-5, Center for Population Economics, University of Chicago and Department of Economics, Brigham Young University. 2000b. Public Use Tape on the Aging of the Veterans of the Union Army Data User's

Manual: U.S. Federal Census Records 1850, 1860, 1900, 1910, Version C-3, Center for Population Economics, University of Chicago and Department of Economics, Brigham Young University. . 2001. Public Use Tape on the Aging of the Veterans of the Union Army Data User's

Manual: Surgeon's Certificates 1862-1940, Version S-1 Standardized, Center for Population Economics, University of Chicago and Department of Economics, Brigham Young University.

Foy D. W., D. B. Rueger, R. C. Sipprelle, and E. H. Carroll. 1984, "Etiology of Post Traumatic Stress Disorder in Vietnam Veterans: Analysis of Premilitary, Military, and Constant Exposure Influences," Journal of Consulting and Clinical Psychology 52, 79-87.

Freeman, Linton C., and Morris H. Sunshine. 1976. "Race and Intra-Urban Migration," Demography 13, 571-575. 
Frye, J. S., and R. A. Stockton. 1982, "Discriminant Analysis of Post Traumatic Stress Disorder among a Group of Vietnam Veterans." American Journal of Psychiatry 139: 52-56.

Galenson, D. W., and C. Pope. 1989. "Economic and Geographic Mobility on the Farming Frontier: Evidence from Appanoose County, Iowa, 1850-1870," Journal of Economic History 49, 635-55.

Geary, J. W. 1991. We Need Men: The Union Draft in the Civil War. Dekalb: Northern Illinois University Press.

Goldin, C. D., and F. D. Lewis. 1975. "The Economic Cost of the American Civil War: Estimates and Implication," Journal of Economic History 35, 299-326.

Goulston, Kerry J. et al. 1985. "Gastrointestinal Morbidity among World War II Prisoners of War: 40 Years On," Medical Journal of Australia 143, 6-10.

Groen, Jeffrey A. 2004. "The Effect of College Location on Migration of College-Educated Labor," Journal of Econometrics 121, 125-142.

Hamersly, T. H. S. 1888. Complete Army and Navy Register of the United States of America, from 1776 to 1887. New York: THS Hammersly, pub.

Hatton, T., and J. Williamson. 1998. The Age of Mass Migration, Oxford University Press.

Hearst, N, T. B. Newman, and S. B. Hulley. 1986. "Delayed Effects of the Military Draft on Mortality: A Randomized Natural Experiment," New England Journal of Medicine 314, 620-624.

Herscovici, S. 1998. "Migration and Economic Mobility: Wealth Accumulation and Occupational Change among Antebellum Migrants and Persisters," Journal of Economic History 58, 927-956.

Herzog, Jr., Henry, Richard A. Hofler, and Alan M. Schlottmann. 1985. "Life on the Frontier: Migrant Information, Earnings, and Past Mobility," Review of Economics and Statistics 67, 373382.

Higgs R. 1979. "Cycles and Trends of Mortality in 18 Large American Cities, 1871-1900," Explorations in Economic History 10, 177-95.

Kau, James B., and C. F. Sirmans. 1977. "The Influence of Information Costs and Uncertainty on Migration: A Comparison of Migrant Types," Journal of Regional Science 17, 89-96.

Kemp, T. R. 1990. "Community and War: The Civil War Experience of Two New Hampshire Towns." In Vinovskis, M. A. ed., Toward A Social History of the American Civil War. New York: Cambridge Univ. Press, 31-77.

Lloyd, Robert E. 1976. "Cognition, Preference, and Behavior in Space: An Examination of the Structural Linkages," Economic Geography 52, 241-253.

Lee, Chulhee. 1997. "Socioeconomic Background, Disease, and Mortality among Union Army Recruits: Implications for Economic and Demographic History," Explorations in Economic History 34, 27-55. 
1999. "Selective Assignment of Military Positions in the Union Army: Implications for the Impact of the Civil War," Social Science History 23, 67-97.

. 2002. "Sectoral Shift and the Labor-Force Participation of Older Males in the United States, 1880-1940," Journal of Economic History 62, 512-523.

. 2003a. "Prior Exposure to Disease, and Later Health and Mortality: Evidence from Civil War Medical Records," In D. Costa, ed., Health and Labor Force Participation over the Life Cycle. Chicago: University of Chicago Press.

2003b. "Health and Wealth Accumulation: Evidence from Nineteenth-Century America," NBER Working Paper No. 10035.

. 2005. "Wealth Accumulation and the Health of Union Army Veterans, 1860-1870," Journal of Economic History, Forthcoming.

Lund M., D. Foy, C. Sipprelle, and A. Strachan. 1984. "The Combat Exposure Scale: A Systematic Assessment of Trauma in the Vietnam War," Journal of Clinical Psychology 40, 1323-328.

Margo, R.A. 1990. Race and Schooling in the South, 1880-1950. Chicago: University of Chicago Press.

McNeil, W. H. 1976. Plagues and People, Garden City, N.Y.: Doubleday.

Meer, J., D. Miller, and H. Rosen. 2003. "Exploring the Health-Wealth Nexus," NBER Working Paper No. 9554.

Murayama, Yuzo. 1991. "Information and Emigrants: Interprefectural Differences of Japanese Emigration to the Pacific Northwest, 1880-1915," Journal of Economic History 51, 125-147.

Mincer, Jacob. 1978. "Family Migration Decisions," Journal of Political Economy 86, 749-773.

Nefzger, M. Dean. 1970. "Follow-up Studies of World War II and Korean War Prisoners, I. Study Plan and Mortality Findings," American Journal of Epidemiology 91, 123-138.

Pizarro, J., R. C. Silver, and J. Prause. 2004. "Traumatic War Experiences and Post-War Lifetime Disease Development among Civil War Veterans," Mimeo, Department of Psychology and Social Behavior, UC Irvine.

Pope, C. L. 1989. "Households on the American Frontier: The Distribution of Income and Wealth in Utah, 1850-1900,” In D. W. Galenson, ed., Markets in History. Cambridge: Cambridge University Press.

Preston, S. H., and Haines, M. R. 1991. Fatal Years: Child Mortality in Late Nineteenth Century America. Princeton NJ: Princeton University Press.

Preston, S. H., Haines, M. R., and Pamuk, E. 1981, "Effects of Industrialization and Urbanization on Mortality in Developed Countries," In International Union for the Scientific Study of Population. International Population Conference, Manila, 1981: Solicited Papers, vol. 2. Liege: 
IUSSP, 233-54.

Pritchett, J. B., and İ. Tunal1. 1995. "Strangers' Disease: Determinants of Yellow Fever Mortality during the New Orleans Epidemic of 1853" Explorations in Economic History 32, 517-539.

Robinson, Chris, and Nigel Tomes. 1982. "Self-Selection and Interprovincial Migration in Canada," Canadian Journal of Economics 15, 474-502.

Sánchez, Mario A. 2003. "Internal Migration, Return Migration, and Mortality: Evidence from Panel Data on Union Army Veterans," In D. Costa, ed., Health and Labor Force Participation over the Life Cycle, University of Chicago Press, 203-230.

Schwartz, Aba. 1973. Interpreting the Effect of Distance on Migration, Journal of Political Economy 81, 1153-1169.

Sjaastad, Larry A. 1962. "The Costs and Returns of Human Migration," Journal of Political Economy, part 2, Supplement 70, 80-93.

Smith, C. I. et al. 1987. "Evidence of Hepatitis Virus Infection among Australian Prisoners of War during World War II," Medial Journal of Austria 147, 229-230.

Smith, J. P. 1999. "Healthy Bodies and Thick Wallets: The Dual Relation between Health and Economic Status," Journal of Economic Perspectives 13, 145-166.

Spaulding R. C. 1977. "The Pueblo Incident: Medical Problems Reported during Captivity and Physical Findings at the Time of the Crew's Release," Military Medicine, 681-684.

Steckel, Richard. 1983. "The Economic Foundation of East-West Migration during the 19th century," Explorations in Economic History 20, 14-36.

Steckel, R. 1988. "The Health and Mortality of Women and Children, 1850-1860," Journal of Economic History 48, 333-45.

. 1995. "Stature and Standard of Living," Journal of Economic Literature 33, 1903-40.

Strauss, J., and D. Thomas. 1992. "Health, Nutrition, and Economic Development," Journal of Economic Literature 36, 766-817.

Sutker, P., D. Winstead, Z. Galina and A. Allan. 1991. "Cognitive Deficits and Psychopathology among Former Prisoners of War and Combat Veterans of the Korean Conflicts," American Journal of Psychiatry 148, 67-72.

Ursano, Robert J. 1990. “The Prisoner of War,” Military Medicine 155, 176-180.

U.S. Bureau of the Census. 1975. Historical Statistics of the United States: Colonial Times to 1970. Washington, DC: Government Printing Office.

U.S. Surgeon General's Office. 1870. Medical and Surgical History of the War of the Rebellion. Washington, DC: Government Printing Office.

Vinovskis, M. A. 1990. "Have Social Historians Lost the Civil War? Some Preliminary 
Demographic Speculations," In Vinovskis, M. A. ed., Toward a Social History of the American Civil War. New York: Cambridge Univ. Press, 1-30.

Wegge, Simone A. 1997. Migration Decisions in Mid Nineteenth-Century Germany, Ph.D. dissertation, Northwestern University.

1998. "Chain Migration and Information Networks: Evidence from NineteenthCentury Hesse-Cassel," Journal of Economic History 58, 957-986.

Wimmer, L. 2003. "Reflections on the 'Early Indicator's Project': A Partial History," In D. Costa, ed., Health and Labor Force Participation over the Life Cycle, University of Chicago Press, 1-10. 
Table 1

Some Characteristics of the Entire and Selected Samples of Union Army Recruits Aged 18 to 45

\begin{tabular}{|c|c|c|c|}
\hline Variables & $\begin{array}{l}\text { Entire Union Army sample } \\
\qquad \mathrm{N}=33,370\end{array}$ & $\begin{array}{l}(2) \\
\text { Sample linked to } \\
\text { the } 1880 \text { census } \\
N=6882\end{array}$ & $\begin{array}{l}\text { Sample linked to } \\
\text { the } 1860 \text { and } 1880 \text { census } \\
\mathrm{N}=3144\end{array}$ \\
\hline \multicolumn{4}{|l|}{ Personal Characteristics } \\
\hline Age in 1860 & 25.6 & 25.3 & 25.3 \\
\hline Height (inch) & 67.6 & 67.7 & 68.0 \\
\hline U.S. born $(\%)$ & 69.0 & 79.1 & 87.9 \\
\hline \multicolumn{4}{|l|}{ Occupational Composition (\%) } \\
\hline Farmers & 49.1 & 53.4 & 61.4 \\
\hline Professionals & 2.3 & 2.4 & 2.6 \\
\hline Managers and proprietors & 5.3 & 5.0 & 3.9 \\
\hline Skilled & 20.1 & 20.7 & 18.4 \\
\hline Semiskilled & 4.7 & 4.1 & 3.3 \\
\hline Unskilled & 16.5 & 12.9 & 9.0 \\
\hline Unclassified & 1.9 & 1.4 & 1.3 \\
\hline \multicolumn{4}{|l|}{ Region of Enlistment (\%) } \\
\hline New England & 7.5 & 9.4 & 11.2 \\
\hline Mid Atlantic & 34.6 & 31.5 & 29.5 \\
\hline East North Central & 42.4 & 42.2 & 42.5 \\
\hline West North Central & 8.4 & 9.0 & 10.0 \\
\hline South & 5.1 & 5.9 & 6.0 \\
\hline West & 2.0 & 2.1 & 0.9 \\
\hline \multicolumn{4}{|l|}{ Year of Enlistment (\%) } \\
\hline 1861 & 24.1 & 23.3 & 21.2 \\
\hline 1862 & 34.2 & 35.5 & 40.3 \\
\hline 1863 & 6.8 & 5.5 & 4.5 \\
\hline 1864 & 23.4 & 23.4 & 23.1 \\
\hline 1865 & 11.4 & 12.3 & 10.9 \\
\hline \multicolumn{4}{|l|}{ Wartime Medical Experience (\%) } \\
\hline All types of wounds & 26.8 & 27.3 & 27.9 \\
\hline Arm/Hand/Finger & 5.0 & 5.7 & 6.0 \\
\hline Leg/Foot/Toe & 6.4 & 6.9 & 7.0 \\
\hline Head/Face & 2.3 & 2.4 & 2.4 \\
\hline Body & 2.7 & 3.0 & 3.0 \\
\hline Unclassified & 16.8 & 16.2 & 16.3 \\
\hline All types of illnesses & 64.0 & 66.7 & 70.5 \\
\hline Typhoid & 5.9 & 5.0 & 5.9 \\
\hline Smallpox & 1.1 & 1.1 & 1.2 \\
\hline Measles & 3.5 & 3.9 & 4.5 \\
\hline Diarrhea & 25.5 & 26.8 & 29.8 \\
\hline Respiratory infections & 6.5 & 6.3 & 5.9 \\
\hline Malaria & 16.2 & 18.4 & 19.4 \\
\hline Tuberculosis & 1.7 & 1.7 & 2.2 \\
\hline Rheumatism & 8.6 & 10.4 & 10.8 \\
\hline Syphilis & 1.4 & 1.3 & 1.0 \\
\hline Hernia & & & \\
\hline \multicolumn{4}{|l|}{ Regions Entered While in Service } \\
\hline Border states & 83.1 & 79.0 & 79.1 \\
\hline South Atlantic & 53.1 & 51.6 & 53.2 \\
\hline East South Central & 53.1 & 53.8 & 54.6 \\
\hline West South Central & 23.8 & 23.2 & 22.6 \\
\hline
\end{tabular}


Table 2

Regional Migration of Veterans from Enlistment to 1880

\begin{tabular}{|c|c|c|c|c|c|c|c|c|c|c|}
\hline \multicolumn{2}{|c|}{$\begin{array}{l}\text { Region of } \\
\text { Residence at } \\
\text { Enlistment }\end{array}$} & \multicolumn{9}{|c|}{ Region of Residence in 1880} \\
\hline & & New & Mid & East N. & West N. & Border & & South & East S. & West S. \\
\hline Region & $\mathrm{N}$ & England & Atlantic & Central & Central & States & West & Atlantic & Central & Central \\
\hline New & 474 & 344 & 36 & 35 & 35 & 3 & 14 & 2 & 0 & 5 \\
\hline England & & $(72.6 \%)$ & $(7.6 \%)$ & $(7.4 \%)$ & $(7.4 \%)$ & $(0.6 \%)$ & $(3.0 \%)$ & $(0.4 \%)$ & $(0 \%)$ & $(1.1 \%)$ \\
\hline Mid & 2142 & 124 & 1435 & 293 & 162 & 42 & 55 & 8 & 5 & 18 \\
\hline Atlantic & & $(5.8)$ & $(67.0 \%)$ & $(13.7 \%)$ & $(7.7 \%)$ & $(2.0)$ & $(2.6 \%)$ & $(0.4 \%)$ & $(0.2)$ & $(0.8)$ \\
\hline East N. & 2872 & 27 & 158 & 1944 & 584 & 55 & 47 & 9 & 9 & 39 \\
\hline Central & & $(0.9 \%)$ & $(5.5 \%)$ & $(67.7 \%)$ & $(20.3 \%)$ & $(1.9 \%)$ & $(1.6 \%)$ & $(0.3 \%)$ & $(0.3 \%)$ & $(1.4 \%)$ \\
\hline West N. & 605 & 7 & 27 & 65 & 447 & 7 & 22 & 2 & 8 & 20 \\
\hline Central & & $(1.2 \%)$ & $(4.5 \%)$ & $(10.7 \%)$ & $(73.9 \%)$ & $(1.2 \%)$ & $(3.6 \%)$ & $(0.3 \%)$ & $(1.3 \%)$ & $(3.3 \%)$ \\
\hline Border & 396 & 11 & 41 & 44 & 37 & 248 & 7 & 1 & 4 & 3 \\
\hline States & & $(2.8 \%)$ & $(10.4 \%)$ & $(11.1 \%)$ & $(9.3 \%)$ & $(62.6 \%)$ & $(1.8 \%)$ & $(0.3 \%)$ & $(1.0 \%)$ & $(0.8 \%)$ \\
\hline West & 141 & $\begin{array}{c}10 \\
(7.1 \%)\end{array}$ & $\begin{array}{c}26 \\
(18.4 \%)\end{array}$ & $\begin{array}{c}23 \\
(16.3 \%)\end{array}$ & $\begin{array}{c}31 \\
(22.0 \%)\end{array}$ & $\begin{array}{c}4 \\
(2.8 \%)\end{array}$ & $\begin{array}{c}39 \\
(27.7 \%)\end{array}$ & $\begin{array}{c}0 \\
(0.0 \%)\end{array}$ & $\begin{array}{c}2 \\
(1.4 \%)\end{array}$ & $\begin{array}{c}6 \\
(4.3 \%)\end{array}$ \\
\hline All & 6630 & $\begin{array}{c}523 \\
(7.9 \%)\end{array}$ & $\begin{array}{c}1723 \\
(18.4 \%)\end{array}$ & $\begin{array}{c}2404 \\
(36.3 \%)\end{array}$ & $\begin{array}{c}1296 \\
(19.6 \%)\end{array}$ & $\begin{array}{c}359 \\
(5.4 \%)\end{array}$ & $\begin{array}{c}184 \\
(2.8 \%)\end{array}$ & $\begin{array}{c}22 \\
(0.3 \%)\end{array}$ & $\begin{array}{c}28 \\
(0.4 \%)\end{array}$ & $\begin{array}{c}91 \\
(1.4 \%)\end{array}$ \\
\hline
\end{tabular}


Table 3

Results of OLS and Logistic Regressions: Correlates of the Distance and Probability of Migration

\begin{tabular}{|c|c|c|c|c|c|c|c|c|c|}
\hline \multirow[t]{2}{*}{ Variable } & \multirow[t]{2}{*}{ Mean } & \multicolumn{2}{|c|}{$\begin{array}{c}(1) \\
\text { Distance of migration in } \\
\text { miles } \\
(\text { OLS }) \\
\text { Mean }=444.203\end{array}$} & \multicolumn{2}{|c|}{$\begin{array}{c}\text { (2) } \\
\text { Probability of moving to } \\
\text { a different county } \\
\text { (Logistic Regression) } \\
\text { Mean=0.777 }\end{array}$} & \multicolumn{2}{|c|}{$\begin{array}{c}(3) \\
\text { Probability of moving to } \\
\text { a different state } \\
\text { (Logistic Regression) } \\
\text { Mean=0.452 }\end{array}$} & \multicolumn{2}{|c|}{$\begin{array}{c}(4) \\
\text { Probability of moving to } \\
\text { a different region } \\
\text { (Logistic Regression) } \\
\text { Mean=0.328 }\end{array}$} \\
\hline & & Parameter & P-value & $\partial P / \partial x_{\mathrm{i}}$ & P-value & $\partial P / \partial x_{\mathrm{i}}$ & P-value & $\partial P / \partial x_{\mathrm{i}}$ & P-value \\
\hline Intercept & & 624.360 & 0.0000 & & & & & & \\
\hline Company Mortality & & & & & & & & & \\
\hline Co wound mortality 1 & 0.224 & $\mathrm{NI}$ & NI & NI & NI & NI & NI & NI & NI \\
\hline Co wound mortality 2 & 0.289 & -16.599 & 0.5229 & -0.073 & 0.4421 & -0.019 & 0.8144 & -0.074 & 0.3814 \\
\hline Co wound mortality 3 & 0.191 & 20.642 & 0.4862 & 0.176 & 0.1542 & 0.085 & 0.3821 & 0.052 & 0.6063 \\
\hline Co wound mortality 4 & 0.297 & -3.467 & 0.8989 & 0.076 & 0.4807 & 0.041 & 0.6376 & 0.002 & 0.9802 \\
\hline Wounds & 0.269 & -34.038 & 0.0837 & -0.202 & 0.0016 & -0.082 & 0.1694 & -0.003 & 0.9642 \\
\hline Illnesses & 0.664 & -57.621 & 0.0021 & -0.242 & 0.0001 & -0.201 & 0.0001 & -0.170 & 0.0027 \\
\hline \multicolumn{10}{|l|}{ Mobility while in service } \\
\hline North-South move & 7.144 & 6.431 & 0.0714 & 0.006 & 0.6732 & 0.010 & 0.3782 & 0.038 & 0.0025 \\
\hline East-West move & 7.438 & 3.588 & 0.3934 & 0.035 & 0.0407 & 0.038 & 0.0058 & 0.036 & 0.0125 \\
\hline NS*EW & 65.825 & -0.196 & 0.5844 & -0.002 & 0.1753 & -0.002 & 0.0396 & -0.003 & 0.0131 \\
\hline 1860 Age & 25.322 & -2.466 & 0.7927 & -0.044 & 0.2074 & -0.014 & 0.6453 & -0.020 & 0.5167 \\
\hline $1860 \mathrm{Age}^{2} \times 10^{-2}$ & 69.265 & 0.033 & 0.9836 & 0.006 & 0.3235 & 0.001 & 0.8757 & 0.003 & 0.5207 \\
\hline \multicolumn{10}{|l|}{ Height } \\
\hline Height $5^{\text {th }}$ quintile & 0.192 & -4.928 & 0.8570 & -0.017 & 0.8646 & -0.066 & 0.4296 & -0.008 & 0.9282 \\
\hline Height $4^{\text {th }}$ quintile & 0.204 & 24.304 & 0.3654 & 0.187 & 0.0933 & 0.114 & 0.2023 & 0.209 & 0.0332 \\
\hline Height $3^{\text {rd }}$ quintile & 0.191 & NI & NI & NI & NI & NI & NI & $\mathrm{NI}$ & NI \\
\hline Height $2^{\text {nd }}$ quintile & 0.223 & 4.949 & 0.8508 & 0.138 & 0.1914 & -0.009 & 0.9149 & 0.029 & 0.7475 \\
\hline Height $1^{\text {st }}$ quintile & 0.190 & 28.203 & 0.3036 & 0.095 & 0.3725 & 0.068 & 0.4455 & 0.065 & 0.4954 \\
\hline \multicolumn{10}{|l|}{ Occupation at enlistment } \\
\hline Farmer & 0.536 & NI & NI & NI & NI & NI & NI & NI & NI \\
\hline Professional & 0.025 & 14.459 & 0.7917 & -0.035 & 0.8589 & -0.035 & 0.8380 & -0.142 & 0.4122 \\
\hline Managers and proprietor & 0.051 & 95.361 & 0.0162 & -0.019 & 0.8946 & 0.212 & 0.1210 & 0.133 & 0.3360 \\
\hline Skilled & 0.208 & 36.918 & 0.1069 & 0.084 & 0.3445 & 0.106 & 0.1619 & -0.060 & 0.4247 \\
\hline Semi-skilled & 0.039 & 69.075 & 0.1213 & 0.109 & 0.5441 & 0.132 & 0.3770 & 0.090 & 0.5503 \\
\hline Unskilled & 0.141 & 90.668 & 0.0014 & 0.101 & 0.3792 & 0.102 & 0.2827 & -0.009 & 0.9210 \\
\hline Unclassified & 0.015 & 180.902 & 0.0096 & 1.011 & 0.0354 & 0.998 & 0.0028 & 0.763 & 0.0125 \\
\hline U.S. born & 0.788 & -248.105 & 0.0000 & -0.324 & 0.0000 & -0.565 & 0.0000 & -0.556 & 0.0000 \\
\hline \multicolumn{10}{|l|}{ Year of Enlistment } \\
\hline 1861 & 0.227 & NI & NI & NI & NI & $\mathrm{NI}$ & NI & NI & NI \\
\hline 1862 & 0.355 & -57.342 & 0.0136 & -0.358 & 0.0000 & 0.045 & 0.5481 & -0.001 & 0.9935 \\
\hline 1863 & 0.054 & 36.901 & 0.3624 & 0.290 & 0.1285 & 0.408 & 0.0074 & 0.170 & 0.2354 \\
\hline 1864 & 0.232 & -68.571 & 0.0111 & 0.027 & 0.7996 & -0.230 & 0.0022 & -0.181 & 0.0391 \\
\hline 1865 & 0.131 & -32.447 & 0.3317 & 0.538 & 0.0019 & -0.019 & 0.8520 & 0.082 & 0.4725 \\
\hline \multicolumn{10}{|l|}{ Region of enlistment } \\
\hline North East Central & 0.434 & NI & NI & NI & NI & NI & NI & NI & NI \\
\hline Mid Atlantic & 0.327 & 59.105 & 0.0062 & -0.215 & 0.0026 & -0.103 & 0.1118 & 0.035 & 0.6347 \\
\hline New England & 0.071 & 70.358 & 0.0619 & -0.350 & 0.0012 & -0.137 & 0.2152 & -0.184 & 0.1155 \\
\hline Border states & 0.058 & -8.767 & 0.8262 & 0.181 & 0.2927 & 0.016 & 0.8968 & 0.346 & 0.0234 \\
\hline North West Central & 0.081 & 67.479 & 0.0328 & 0.275 & 0.0551 & 0.257 & 0.0199 & -0.203 & 0.0376 \\
\hline West & 0.020 & 1896.960 & 0.0000 & 6.440 & 0.0001 & 4.954 & 0.0000 & 5.437 & 0.0000 \\
\hline & & \multicolumn{2}{|c|}{$\begin{array}{lc}\mathrm{R}^{2}: & 0.173 \\
\text { F-value: } & 41.11\end{array}$} & \multicolumn{2}{|c|}{$\begin{array}{l}\text {-2 Log L: } 6165.432 \\
\text { Chi-square: } 218.125\end{array}$} & \multicolumn{2}{|c|}{$\begin{array}{l}\text {-2 Log L: } 8101.095 \\
\text { Chi-square: } 299.406\end{array}$} & \multicolumn{2}{|c|}{$\begin{array}{l}\text {-2 Log L: } 7418.190 \\
\text { Chi-square: } 286.244\end{array}$} \\
\hline & & \multicolumn{2}{|c|}{ P-value: 0.0000} & P-value: & .0000 & P-value: & .0000 & P-value: & 0.0000 \\
\hline
\end{tabular}

Note: The sample is limited to 6124 veterans who were linked to the 1880 censuses and for whom information on all independent variables is given. NI stands for "Not Included." The dependent variable for regression (1) is the distance between the places of enlistment and of residence in 1880 . The dependent variables for logistic regressions (2) to (4) have a value of one if a veteran moved, and zero otherwise. 
Table 4

Results of OLS and Logistic Regressions:

Effects of Particular Types of Wounds and Illnesses on the Distance and Probability of Migration

\begin{tabular}{|c|c|c|c|c|c|c|c|c|c|}
\hline \multirow[t]{2}{*}{ Variable } & \multirow[t]{2}{*}{ Mean } & \multicolumn{2}{|c|}{$\begin{array}{c}(1) \\
\text { Distance of migration in } \\
\text { miles } \\
(\text { OLS }) \\
\text { Mean }=444.203\end{array}$} & \multicolumn{2}{|c|}{$\begin{array}{c}\text { (2) } \\
\text { Probability of moving to a } \\
\text { different county } \\
\text { (Logistic Regression) } \\
\text { Mean }=0.777\end{array}$} & \multicolumn{2}{|c|}{$\begin{array}{c}(3) \\
\text { Probability of moving } \\
\text { to a different state } \\
\text { (Logistic Regression) } \\
\text { Mean=0.452 }\end{array}$} & \multicolumn{2}{|c|}{$\begin{array}{c}\text { (4) } \\
\text { Probability of moving to } \\
\text { a different region } \\
\text { (Logistic Regression) } \\
\text { Mean=0.328 }\end{array}$} \\
\hline & & Parameter & $\mathrm{P}$-value & $\partial P / \partial x_{\mathrm{i}}$ & P-value & $\partial P / \partial x_{\mathrm{i}}$ & P-value & $\partial P / \partial x_{\mathrm{i}}$ & P-value \\
\hline Intercept & & 593.407 & 0.0000 & & & & & & \\
\hline Company Mortality & & & & & & & & & \\
\hline Co wound mortality 1 & 0.224 & NI & NI & NI & NI & NI & NI & NI & NI \\
\hline Co wound mortality 2 & 0.289 & -20.407 & 0.4334 & -0.078 & 0.4128 & -0.030 & 0.7143 & -0.079 & 0.3448 \\
\hline Co wound mortality 3 & 0.191 & 16.567 & 0.5769 & 0.158 & 0.1956 & 0.071 & 0.4617 & 0.047 & 0.6444 \\
\hline Co wound mortality 4 & 0.297 & -10.545 & 0.7004 & 0.049 & 0.6470 & 0.016 & 0.8508 & -0.005 & 0.9539 \\
\hline \multicolumn{10}{|l|}{ Illnesses by type } \\
\hline Typhoid & 0.049 & -46.727 & 0.2331 & -0.193 & 0.1208 & -0.104 & 0.3772 & -0.151 & 0.2215 \\
\hline Smallpox & 0.011 & -28.582 & 0.7245 & -0.048 & 0.8668 & -0.184 & 0.4320 & -0.067 & 0.8012 \\
\hline Measles & 0.038 & -89.935 & 0.0437 & -0.050 & 0.7602 & -0.183 & 0.1520 & -0.153 & 0.2826 \\
\hline Diarrhea & 0.264 & -8.653 & 0.6642 & -0.134 & 0.0510 & -0.051 & 0.4084 & -0.092 & 0.1538 \\
\hline Respiratory infections & 0.064 & 24.890 & 0.4754 & 0.172 & 0.2295 & -0.043 & 0.6905 & -0.021 & 0.8552 \\
\hline Malaria & 0.182 & -10.017 & 0.6571 & -0.184 & 0.0134 & -0.059 & 0.3890 & 0.016 & 0.8328 \\
\hline Tuberculosis & 0.018 & -76.502 & 0.2262 & -0.229 & 0.2323 & 0.078 & 0.7036 & -0.330 & 0.0832 \\
\hline Rheumatism & 0.102 & 4.228 & 0.8814 & 0.040 & 0.7082 & 0.122 & 0.1967 & 0.146 & 0.1442 \\
\hline Syphilis & 0.012 & 98.341 & 0.2188 & -0.198 & 0.4736 & 0.056 & 0.8346 & 0.484 & 0.1319 \\
\hline Hernia & 0.021 & -16.317 & 0.7831 & -0.099 & 0.6189 & 0.124 & 0.5301 & 0.184 & 0.3829 \\
\hline \multicolumn{10}{|l|}{ Wounds by location } \\
\hline Arm/Hand/Finger & 0.054 & 26.942 & 0.4769 & -0.129 & 0.3082 & 0.077 & 0.5330 & 0.219 & 0.1092 \\
\hline Leg/Foot/Toe & 0.069 & -46.634 & 0.1705 & -0.245 & 0.0187 & -0.169 & 0.0858 & -0.120 & 0.2682 \\
\hline Head/Face & 0.024 & -18.279 & 0.7434 & 0.184 & 0.4391 & 0.040 & 0.8237 & -0.002 & 0.9896 \\
\hline Body & 0.030 & -25.572 & 0.6037 & -0.241 & 0.1075 & -0.110 & 0.4539 & -0.125 & 0.4274 \\
\hline Unclassified & 0.159 & -7.211 & 0.7708 & -0.060 & 0.4959 & -0.006 & 0.9423 & -0.027 & 0.8382 \\
\hline \multicolumn{10}{|l|}{ Mobility in service } \\
\hline North-South move & 7.144 & 5.725 & 0.1086 & 0.004 & 0.7785 & 0.007 & 0.5437 & 0.036 & 0.0042 \\
\hline East-West move & 7.438 & 3.763 & 0.3722 & 0.032 & 0.0593 & 0.038 & 0.0065 & 0.037 & 0.0118 \\
\hline NS*EW & 65.825 & -0.195 & 0.5881 & -0.002 & 0.2509 & -0.002 & 0.0501 & -0.003 & 0.0139 \\
\hline & & \multicolumn{2}{|c|}{$\begin{array}{lr}\mathrm{R}^{2}: & 0.173 \\
\text { F-value: } & 28.89\end{array}$} & \multicolumn{2}{|c|}{$\begin{array}{l}\text {-2 Log L: } \quad 6160.782 \\
\text { Chi-square: } 223.600\end{array}$} & \multicolumn{2}{|c|}{$\begin{array}{ll}\text {-2 Log L: } & 8441.279 \\
\text { Chi-square: } & 294.834\end{array}$} & \multicolumn{2}{|c|}{$\begin{array}{ll}\text {-2 Log L: } & 7409.314 \\
\text { Chi-square: } & 293.245\end{array}$} \\
\hline & & \multicolumn{2}{|c|}{ P-value: $\quad 0.0000$} & P-value: & 0000 & P-value: & 0.0000 & P-value: & 0000 \\
\hline
\end{tabular}

Note: The same sample and specification as those used in the regressions reported in Table 3 are used, except the variables on wounds and illnesses. 
Table 5

Results of OLS and Logistic Regressions:

Various Measures of War-Time Geographical Movements and Post-War Migration

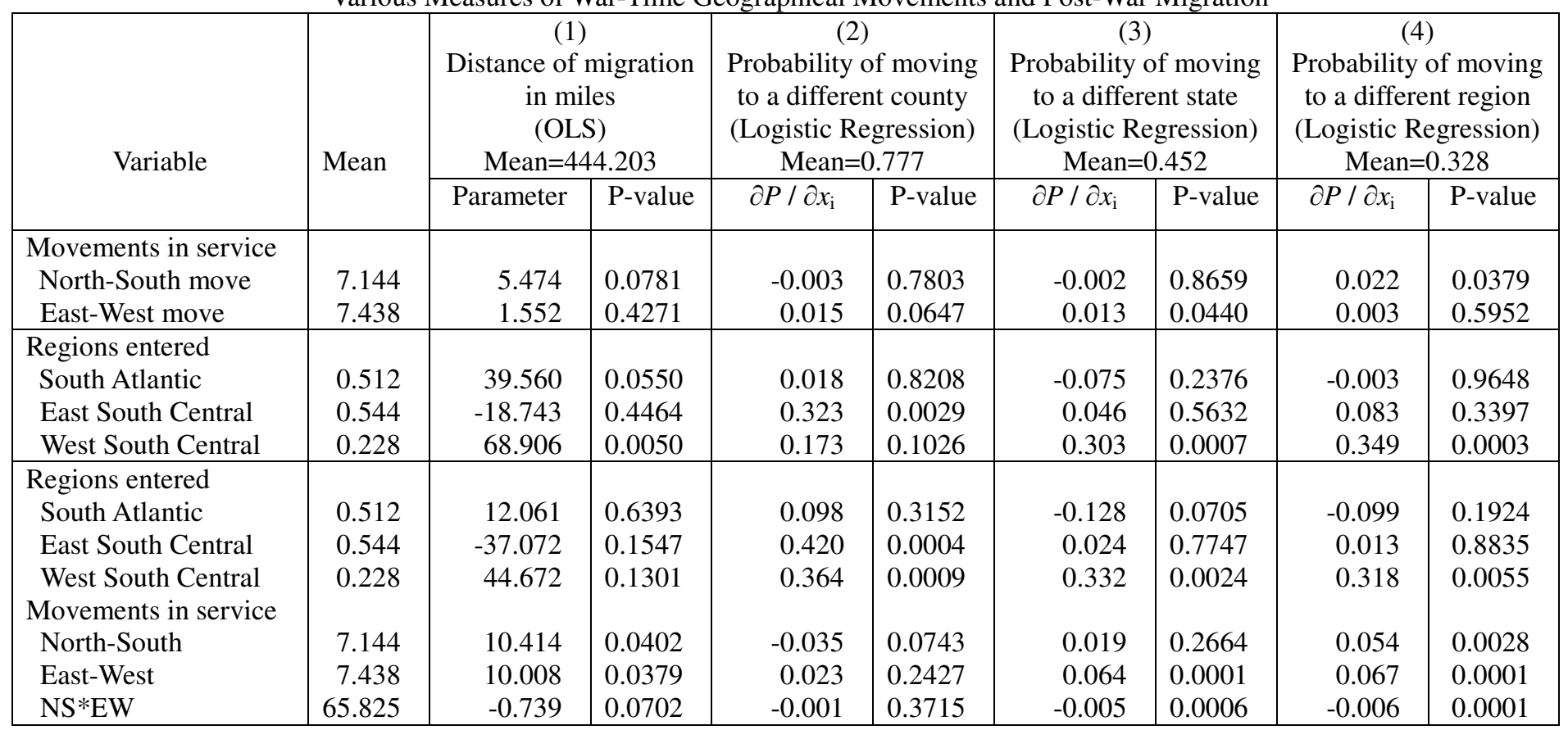

Note: The same sample and specification as those used in the regressions reported in Table 3 are used, except the variables on the measures of war-time geographical movements. 
Table 6

Results of OLS and Logistic Regressions:

Wartime Experiences and Post-War Migration by Age, Occupation, and Nativity

\begin{tabular}{|c|c|c|c|c|c|c|c|c|c|}
\hline \multirow[t]{2}{*}{ Variable } & \multirow[t]{2}{*}{ Mean } & \multicolumn{2}{|c|}{$\begin{array}{c}(1) \\
\text { Distance of migration in } \\
\text { miles } \\
(\text { OLS }) \\
\text { Mean }=444.203\end{array}$} & \multicolumn{2}{|c|}{$\begin{array}{l}\text { (2) } \\
\text { Probability of moving to } \\
\text { a different county } \\
\text { (Logistic Regression) } \\
\text { Mean }=0.777\end{array}$} & \multicolumn{2}{|c|}{$\begin{array}{l}\text { (3) } \\
\text { Probability of moving to } \\
\text { a different state } \\
\text { (Logistic Regression) } \\
\text { Mean=0.452 }\end{array}$} & \multicolumn{2}{|c|}{$\begin{array}{c}(4) \\
\text { Probability of moving to } \\
\text { a different region } \\
\text { (Logistic Regression) } \\
\text { Mean }=0.328\end{array}$} \\
\hline & & Parameter & P-value & $\partial P / \partial x_{\mathrm{i}}$ & P-value & $\partial P / \partial x_{\mathrm{i}}$ & P-value & $\partial P / \partial x_{\mathrm{i}}$ & P-value \\
\hline $\begin{array}{l}\text { A. Age under 30 } \\
\text { Wounds } \\
\text { Illnesses } \\
\text { North-South move } \\
\text { East-West move } \\
\text { NS*EW } \\
\end{array}$ & $\begin{array}{r}0.284 \\
0.670 \\
7.223 \\
7.499 \\
66.476 \\
\end{array}$ & $\begin{array}{r}-36.153 \\
-63.211 \\
7.798 \\
6.236 \\
-0.355 \\
\end{array}$ & $\begin{array}{l}0.1084 \\
0.0036 \\
0.0588 \\
0.2057 \\
0.3905 \\
\end{array}$ & $\begin{array}{r}-0.219 \\
-0.237 \\
0.021 \\
0.055 \\
-0.004 \\
\end{array}$ & $\begin{array}{l}0.0027 \\
0.0014 \\
0.1650 \\
0.0057 \\
0.0118 \\
\end{array}$ & $\begin{array}{r}-0.080 \\
-0.221 \\
0.016 \\
0.045 \\
-0.003 \\
\end{array}$ & $\begin{array}{l}0.2392 \\
0.0003 \\
0.2182 \\
0.0056 \\
0.0300 \\
\end{array}$ & $\begin{array}{r}-0.008 \\
-0.196 \\
0.046 \\
0.039 \\
-0.003 \\
\end{array}$ & $\begin{array}{l}0.9191 \\
0.0025 \\
0.0019 \\
0.0233 \\
0.0196 \\
\end{array}$ \\
\hline $\begin{array}{l}\text { B. Age 30 and older } \\
\text { Wounds } \\
\text { Illnesses } \\
\text { North-South move } \\
\text { East-West move } \\
\text { NS*EW } \\
\end{array}$ & $\begin{array}{r}0.227 \\
0.646 \\
6.900 \\
7.296 \\
64.358 \\
\end{array}$ & $\begin{array}{r}-0.185 \\
-47.969 \\
3.151 \\
-7.483 \\
0.534 \\
\end{array}$ & $\begin{array}{l}0.9963 \\
0.1818 \\
0.6458 \\
0.3341 \\
0.4310 \\
\end{array}$ & $\begin{array}{r}-0.072 \\
-0.215 \\
-0.017 \\
0.002 \\
0.001 \\
\end{array}$ & $\begin{array}{l}0.5525 \\
0.0783 \\
0.5143 \\
0.9498 \\
0.7090 \\
\end{array}$ & $\begin{array}{r}0.026 \\
-0.128 \\
0.003 \\
0.016 \\
-0.001 \\
\end{array}$ & $\begin{array}{l}0.8379 \\
0.2332 \\
0.9054 \\
0.5189 \\
0.5222 \\
\end{array}$ & $\begin{array}{r}0.133 \\
-0.078 \\
0.018 \\
0.019 \\
-0.002 \\
\end{array}$ & $\begin{array}{l}0.3418 \\
0.4996 \\
0.4372 \\
0.4786 \\
0.4557 \\
\end{array}$ \\
\hline $\begin{array}{l}\text { C. Farmers } \\
\text { Wounds } \\
\text { Illnesses } \\
\text { North-South move } \\
\text { East-West move } \\
\text { NS*EW }\end{array}$ & $\begin{array}{r}0.256 \\
0.716 \\
7.640 \\
7.806 \\
70.357 \\
\end{array}$ & $\begin{array}{r}-7.288 \\
-31.233 \\
9.209 \\
2.503 \\
-0.309\end{array}$ & $\begin{array}{l}0.7408 \\
0.1449 \\
0.0216 \\
0.6108 \\
0.4331\end{array}$ & $\begin{array}{r}-0.212 \\
-0.192 \\
0.009 \\
0.028 \\
-0.002 \\
\end{array}$ & $\begin{array}{l}0.0144 \\
0.0378 \\
0.6042 \\
0.2355 \\
0.2347\end{array}$ & $\begin{array}{r}0.055 \\
-0.131 \\
0.017 \\
0.048 \\
-0.003\end{array}$ & $\begin{array}{l}0.5317 \\
0.0932 \\
0.2945 \\
0.0154 \\
0.0409\end{array}$ & $\begin{array}{r}0.123 \\
-0.098 \\
0.065 \\
0.058 \\
-0.005\end{array}$ & $\begin{array}{l}0.2025 \\
0.2495 \\
0.0005 \\
0.0090 \\
0.0056\end{array}$ \\
\hline $\begin{array}{l}\text { D. Professionals } \\
\text { Wounds } \\
\text { Illnesses } \\
\text { North-South move } \\
\text { East-West move } \\
\text { NS*EW }\end{array}$ & $\begin{array}{r}0.278 \\
0.573 \\
6.801 \\
7.269 \\
63.837 \\
\end{array}$ & $\begin{array}{r}-67.680 \\
-17.909 \\
-18.078 \\
-8.979 \\
2.168 \\
\end{array}$ & $\begin{array}{l}0.4203 \\
0.8125 \\
0.2937 \\
0.6283 \\
0.2209 \\
\end{array}$ & $\begin{array}{r}-0.451 \\
-0.271 \\
-0.044 \\
-0.108 \\
0.013 \\
\end{array}$ & $\begin{array}{l}0.0301 \\
0.2111 \\
0.4874 \\
0.0826 \\
0.0817 \\
\end{array}$ & $\begin{array}{r}-0.258 \\
-0.109 \\
-0.088 \\
-0.069 \\
0.011 \\
\end{array}$ & $\begin{array}{l}0.2198 \\
0.5899 \\
0.0956 \\
0.2043 \\
0.0621 \\
\end{array}$ & $\begin{array}{r}-0.278 \\
-0.095 \\
-0.040 \\
-0.043 \\
0.007 \\
\end{array}$ & $\begin{array}{l}0.2007 \\
0.6587 \\
0.4258 \\
0.4246 \\
0.2157 \\
\end{array}$ \\
\hline $\begin{array}{l}\text { E. Skilled } \\
\text { Wounds } \\
\text { Illnesses } \\
\text { North-South move } \\
\text { East-West move } \\
\text { NS*EW }\end{array}$ & $\begin{array}{r}0.290 \\
0.630 \\
6.510 \\
6.859 \\
58.435 \\
\end{array}$ & $\begin{array}{r}-68.831 \\
-118.985 \\
15.538 \\
6.890 \\
-0.776\end{array}$ & $\begin{array}{l}0.1433 \\
0.0079 \\
0.0724 \\
0.5137 \\
0.3826\end{array}$ & $\begin{array}{r}-0.188 \\
-0.298 \\
0.000 \\
0.084 \\
-0.004 \\
\end{array}$ & $\begin{array}{l}0.1802 \\
0.0231 \\
0.9884 \\
0.0499 \\
0.3194\end{array}$ & $\begin{array}{r}-0.129 \\
-0.274 \\
0.024 \\
0.022 \\
-0.003 \\
\end{array}$ & $\begin{array}{l}0.3041 \\
0.0123 \\
0.3424 \\
0.4775 \\
0.2920\end{array}$ & $\begin{array}{r}-0.010 \\
-0.213 \\
0.042 \\
0.036 \\
-0.003\end{array}$ & $\begin{array}{l}0.9432 \\
0.0739 \\
0.1240 \\
0.2622 \\
0.2938\end{array}$ \\
\hline $\begin{array}{l}\text { F. Unskilled } \\
\text { Wounds } \\
\text { Illnesses } \\
\text { North-South move } \\
\text { East-West move } \\
\text { NS*EW } \\
\end{array}$ & $\begin{array}{r}0.285 \\
0.584 \\
6.583 \\
7.151 \\
62.632 \\
\end{array}$ & $\begin{array}{r}-30.538 \\
-68.610 \\
-6.989 \\
9.819 \\
-0.106 \\
\end{array}$ & $\begin{array}{l}0.6242 \\
0.2313 \\
0.5652 \\
0.4547 \\
0.9329 \\
\end{array}$ & $\begin{array}{r}0.077 \\
-0.288 \\
-0.006 \\
0.095 \\
-0.005 \\
\end{array}$ & $\begin{array}{l}0.6942 \\
0.0618 \\
0.8762 \\
0.0453 \\
0.2002 \\
\end{array}$ & $\begin{array}{r}-0.275 \\
-0.298 \\
0.020 \\
0.080 \\
-0.005 \\
\end{array}$ & $\begin{array}{l}0.0435 \\
0.0152 \\
0.5338 \\
0.0262 \\
0.1414 \\
\end{array}$ & $\begin{array}{r}-0.111 \\
-0.273 \\
0.018 \\
0.066 \\
-0.005 \\
\end{array}$ & $\begin{array}{l}0.4744 \\
0.0332 \\
0.5925 \\
0.0764 \\
0.1450 \\
\end{array}$ \\
\hline $\begin{array}{l}\text { G. Natives } \\
\text { Wounds } \\
\text { Illnesses } \\
\text { North-South move } \\
\text { East-West move } \\
\text { NS*EW }\end{array}$ & $\begin{array}{r}0.263 \\
0.685 \\
7.087 \\
7.395 \\
64.864 \\
\end{array}$ & $\begin{array}{r}-25.926 \\
-58.966 \\
6.461 \\
-3.620 \\
0.118 \\
\end{array}$ & $\begin{array}{l}0.1931 \\
0.0020 \\
0.0796 \\
0.4024 \\
0.7483\end{array}$ & $\begin{array}{r}-0.180 \\
-0.277 \\
0.016 \\
0.039 \\
-0.003 \\
\end{array}$ & $\begin{array}{l}0.0127 \\
0.0000 \\
0.2844 \\
0.0450 \\
0.0843 \\
\end{array}$ & $\begin{array}{r}-0.040 \\
-0.191 \\
0.013 \\
0.023 \\
-0.002 \\
\end{array}$ & $\begin{array}{l}0.5660 \\
0.0016 \\
0.3151 \\
0.1431 \\
0.1921 \\
\end{array}$ & $\begin{array}{r}0.016 \\
-0.171 \\
0.054 \\
0.039 \\
-0.004 \\
\end{array}$ & $\begin{array}{l}0.8312 \\
0.0100 \\
0.0005 \\
0.0285 \\
0.0115\end{array}$ \\
\hline $\begin{array}{l}\text { H. Foreign-born } \\
\text { Wounds } \\
\text { Illnesses } \\
\text { North-South move } \\
\text { East-West move } \\
\text { NS*EW }\end{array}$ & $\begin{array}{r}0.287 \\
0.585 \\
7.355 \\
7.601 \\
69.395\end{array}$ & $\begin{array}{r}-54.500 \\
-50.284 \\
4.709 \\
17.910 \\
-0.774\end{array}$ & $\begin{array}{l}0.3331 \\
0.3343 \\
0.6247 \\
0.1217 \\
0.4320\end{array}$ & $\begin{array}{r}-0.280 \\
-0.060 \\
-0.035 \\
0.011 \\
0.005\end{array}$ & $\begin{array}{l}0.0555 \\
0.7160 \\
0.2885 \\
0.7951 \\
0.6601\end{array}$ & $\begin{array}{r}-0.179 \\
-0.226 \\
0.002 \\
0.079 \\
-0.004\end{array}$ & $\begin{array}{l}0.1572 \\
0.0506 \\
0.9374 \\
0.0113 \\
0.0798\end{array}$ & $\begin{array}{r}-0.002 \\
-0.162 \\
0.001 \\
0.026 \\
-0.001\end{array}$ & $\begin{array}{l}0.9876 \\
0.1600 \\
0.9781 \\
0.3563 \\
0.5798\end{array}$ \\
\hline
\end{tabular}

Note: The same sample and similar specification as those used in the regressions reported in Table 3 are used, except that the variables on age (for $\mathrm{A}$ and $\mathrm{B}$ ), occupation (for $\mathrm{C}$ to $\mathrm{F}$ ), or nativity ( $\mathrm{G}$ and $\mathrm{H}$ ) are omitted from the regressions. 
Table 7

Logistic Regressions: Correlates of the Probability of Moving to the South among the Migrants from the North

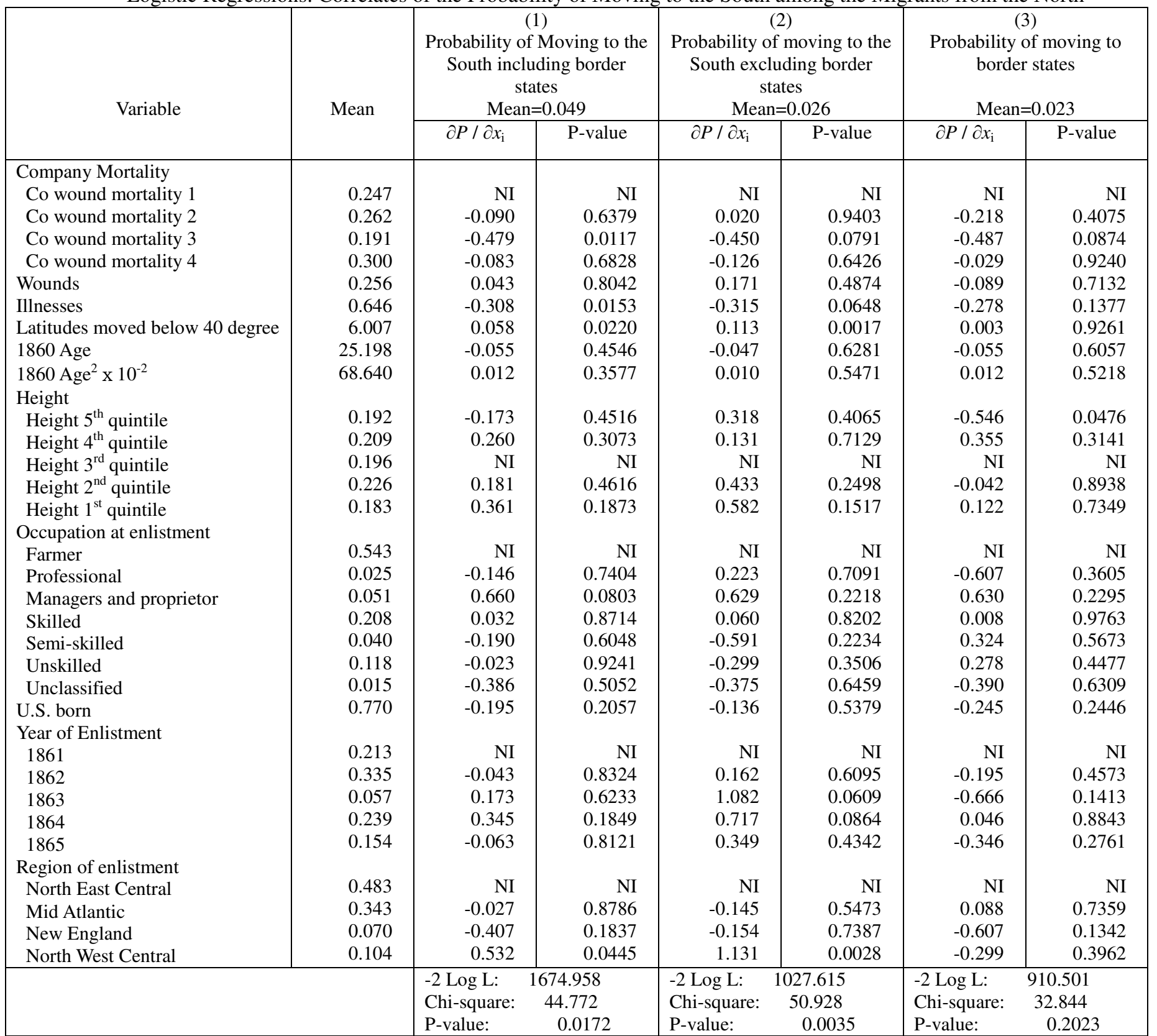


Table 8

Conditional Logistic Regressions: Correlates of the Probability of Migration to a Particular State among Migrants to the South

\[ \text { Variable } \]
Entered in service
Latitudinal distance
Longitudinal distance
Population growth

Mean
0.292
6.122
8.031
187.237

(1)

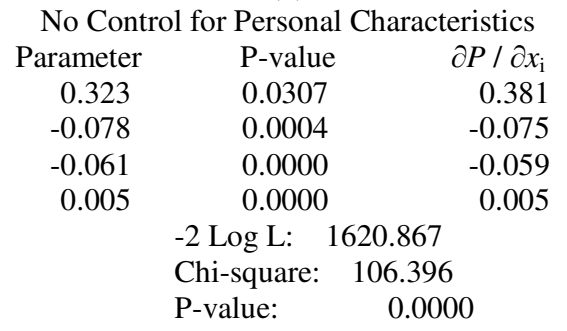

(2)

Control for Personal Characteristics

$\begin{array}{rcr}\text { Parameter } & \text { P-value } & \partial P / \partial x_{\mathrm{i}} \\ 0.304 & 0.050 & 0.356 \\ -0.088 & 0.0001 & -0.084 \\ -0.071 & 0.0000 & -0.068 \\ 0.005 & 0.0000 & 0.005 \\ & \text {-2 Log L: } 1612.598 & \\ & \text { Chi-square: } & 114.665 \\ & \text { P-value: } \quad 0.0000\end{array}$


Appendix Table 1

Classification of Regions

Region

New England

Mid Atlantic

East North Central

West North Central

Border States

West

South Atlantic

East South Central

WestSouth Central

ME, NH, VT, MA, RI, CT

States included

NY, NJ, PA, DE

MI, OH, IN, WI, IL

IA, KS, MO, MN, NE, SD, ND

VA, KY, MD, WV, DC

AZ, CA, MT, NM, NV, OR, UT, WS, WY

$\mathrm{NC}, \mathrm{SC}, \mathrm{GA}, \mathrm{FL}$

TN, MS, AL,

AR, OK, TX, LA 
Appendix Table 2

Correlates of the Distance and Probability of Migration for the Sample Linked to the 1860 Census

\begin{tabular}{|c|c|c|c|c|c|c|c|c|c|}
\hline \multirow[t]{2}{*}{ Variable } & \multirow[t]{2}{*}{ Mean } & \multicolumn{2}{|c|}{$\begin{array}{c}(1) \\
\text { Distance of migration in } \\
\text { miles } \\
(\text { OLS) } \\
\text { Mean=348.502 }\end{array}$} & \multicolumn{2}{|c|}{$\begin{array}{c}(2) \\
\text { Probability of moving to } \\
\text { a different county } \\
\text { (Logistic Regression) } \\
\text { Mean }=0.724\end{array}$} & \multicolumn{2}{|c|}{$\begin{array}{c}\text { (3) } \\
\text { Probability of moving to } \\
\text { a different state } \\
\text { (Logistic Regression) } \\
\text { Mean }=0.452\end{array}$} & \multicolumn{2}{|c|}{$\begin{array}{c}(4) \\
\text { Probability of moving to } \\
\text { a different region } \\
\text { (Logistic Regression) } \\
\text { Mean=0.266 }\end{array}$} \\
\hline & & Parameter & P-value & $\partial \mathrm{P} / \partial x$ & P-value & $\partial \mathrm{P} / \partial x$ & P-value & $\partial \mathrm{P} / \partial x$ & P-value \\
\hline Intercept & & 532.858 & 0.0047 & & & & & & \\
\hline Company Mortality & & & & & & & & & \\
\hline Co wound mortality 1 & 0.226 & NI & NI & NI & & NI & NI & NI & NI \\
\hline Co wound mortality 2 & 0.271 & -49.811 & 0.1428 & -0.259 & 0.0332 & -0.069 & 0.5786 & -0.180 & 0.1683 \\
\hline Co wound mortality 3 & 0.190 & -54.875 & 0.1643 & -0.148 & 0.3245 & -0.101 & 0.4264 & -0.209 & 0.1525 \\
\hline Co wound mortality 4 & 0.313 & -12.204 & 0.7335 & -0.139 & 0.3113 & 0.044 & 0.7502 & -0.068 & 0.6345 \\
\hline Wounds & 0.270 & -55.625 & 0.0290 & -0.291 & 0.0005 & -0.043 & 0.6402 & 0.071 & 0.5106 \\
\hline Illnesses & 0.702 & -27.390 & 0.2731 & -0.141 & 0.1371 & -0.050 & 0.5827 & -0.044 & 0.6677 \\
\hline \multicolumn{10}{|l|}{ Movements in service } \\
\hline Latitudes moved & 7.212 & 11.672 & 0.0104 & 0.012 & 0.5113 & 0.022 & 0.1999 & 0.074 & 0.0005 \\
\hline Longitudes moved & 7.384 & 0.047 & 0.9934 & 0.028 & 0.2512 & 0.004 & 0.8599 & 0.039 & 0.1140 \\
\hline Latitude*Longitude & 66.575 & -0.179 & 0.6813 & -0.002 & 0.2650 & -0.001 & 0.7428 & -0.004 & 0.0419 \\
\hline 1860 Age & 25.337 & 0.698 & 0.9561 & -0.045 & 0.3693 & -0.015 & 0.7524 & -0.057 & 0.2587 \\
\hline $1860 \mathrm{Age}^{2} \times 10^{-2}$ & 69.574 & -0.679 & 0.7491 & 0.007 & 0.4394 & 0.002 & 0.7603 & 0.009 & 0.3004 \\
\hline \multicolumn{10}{|l|}{ Height } \\
\hline Height $5^{\text {th }}$ quintile & 0.162 & 6.517 & 0.8571 & -0.099 & 0.4720 & -0.082 & 0.5309 & -0.031 & 0.8359 \\
\hline Height $4^{\text {th }}$ quintile & 0.176 & 6.449 & 0.8553 & 0.087 & 0.5615 & 0.217 & 0.1359 & 0.186 & 0.2370 \\
\hline Height $3^{\text {rd }}$ quintile & 0.204 & NI & NI & NI & NI & NI & NI & NI & NI \\
\hline Height $2^{\text {nd }}$ quintile & 0.235 & 12.690 & 0.7003 & 0.009 & 0.9453 & 0.020 & 0.8717 & -0.001 & 0.9957 \\
\hline Height $1^{\text {st }}$ quintile & 0.222 & 19.114 & 0.5690 & 0.116 & 0.4213 & 0.005 & 0.9712 & -0.080 & 0.5545 \\
\hline \multicolumn{10}{|l|}{ Occupation at enlistment } \\
\hline Farmer & 0.619 & NI & NI & NI & NI & NI & NI & NI & NI \\
\hline Professional & 0.026 & -26.482 & 0.7001 & 0.226 & 0.4746 & -0.036 & 0.8852 & -0.221 & 0.3812 \\
\hline Managers and proprietor & 0.040 & -26.423 & 0.6404 & -0.301 & 0.0963 & -0.039 & 0.8529 & -0.139 & 0.5303 \\
\hline Skilled & 0.183 & -4.387 & 0.8843 & 0.188 & 0.1589 & -0.072 & 0.5109 & -0.240 & 0.0309 \\
\hline Semi-skilled & 0.031 & -22.028 & 0.7267 & -0.016 & 0.9484 & -0.303 & 0.1435 & -0.362 & 0.1012 \\
\hline Unskilled & 0.087 & 87.967 & 0.0349 & 0.325 & 0.1023 & 0.079 & 0.6315 & -0.124 & 0.4507 \\
\hline Unclassified & 0.014 & 406.593 & 0.0000 & 0.886 & 0.1687 & 1.137 & 0.0292 & 2.421 & 0.0005 \\
\hline U.S. born & 0.883 & -198.850 & 0.0000 & -0.153 & 0.2538 & -0.436 & 0.0000 & -0.508 & 0.0000 \\
\hline \multicolumn{10}{|l|}{ Year of Enlistment } \\
\hline 1861 & 0.202 & NI & NI & NI & NI & NI & NI & NI & NI \\
\hline 1862 & 0.402 & -57.294 & 0.0620 & -0.323 & 0.0017 & 0.042 & 0.7117 & -0.021 & 0.8648 \\
\hline 1863 & 0.044 & 39.733 & 0.4883 & -0.133 & 0.5458 & 0.059 & 0.7824 & -0.125 & 0.5711 \\
\hline 1864 & 0.231 & -104.583 & 0.0048 & -0.167 & 0.2289 & -0.433 & 0.0000 & -0.405 & 0.0010 \\
\hline 1865 & 0.121 & -80.854 & 0.0726 & 0.312 & 0.1721 & -0.226 & 0.1282 & -0.085 & 0.6236 \\
\hline \multicolumn{10}{|l|}{ Region of enlistment } \\
\hline North East Central & 0.437 & NI & NI & NI & NI & NI & NI & NI & \\
\hline Mid Atlantic & 0.312 & 39.901 & 0.1615 & -0.255 & 0.0088 & -0.181 & 0.0626 & 0.115 & 0.3473 \\
\hline New England & 0.078 & -7.959 & 0.8657 & -0.447 & 0.0009 & -0.323 & 0.0280 & -0.415 & 0.0108 \\
\hline Border states & 0.061 & -42.689 & 0.3978 & 0.710 & 0.0216 & -0.081 & 0.6573 & 0.160 & 0.4806 \\
\hline North West Central & 0.102 & 27.656 & 0.4842 & 0.186 & 0.3064 & 0.198 & 0.2079 & -0.373 & 0.0064 \\
\hline West & 0.009 & 1881.618 & 0.0000 & 7.305 & 0.0415 & 4.202 & 0.0010 & 5.790 & 0.0000 \\
\hline \multicolumn{10}{|l|}{ Census information } \\
\hline Log of real estate wealth & 1.072 & -2.797 & 0.6052 & -0.010 & 0.6469 & -0.032 & 0.1055 & -0.011 & 0.6041 \\
\hline Log of personal wealth & 4.435 & 1.883 & 0.6499 & 0.038 & 0.0255 & 0.012 & 0.4512 & 0.035 & 0.0470 \\
\hline Illiterate & 0.031 & -51.304 & 0.4219 & 0.337 & 0.3005 & -0.301 & 0.1501 & -0.309 & 0.0679 \\
\hline Married, no children & 0.311 & -17.628 & 0.7371 & -0.066 & 0.7411 & 0.014 & 0.9422 & 0.025 & 0.9110 \\
\hline \multirow[t]{3}{*}{ Married with children } & 0.257 & \multirow{3}{*}{\multicolumn{2}{|c|}{\begin{tabular}{c|c}
.191 & 0.1685 \\
& 0.127 \\
e: & 10.96 \\
e: & 0.0000
\end{tabular}}} & 0.054 & 0.7333 & 0.134 & 0.3736 & 0.481 & 0.0122 \\
\hline & & & & $\begin{array}{l}\text {-2 Log L: } \\
\text { Chi-square: }\end{array}$ & $\begin{array}{l}2.347 \\
.244\end{array}$ & $\begin{array}{l}\text {-2 Log L: } 3 \\
\text { Chi-square: }\end{array}$ & $\begin{array}{l}1.403 \\
2.742\end{array}$ & $\begin{array}{l}\text {-2 Log L: } \\
\text { Chi-square }\end{array}$ & $\begin{array}{l}16.756 \\
3.854\end{array}$ \\
\hline & & & & P-value: & .0000 & P-value: & .0000 & P-value: & 0.0000 \\
\hline
\end{tabular}

Note: The sample is limited to 2744 veterans who were linked to the 1880 censuses and for whom information on all independent variables is given.

NI stands for "Not Included." The dependent variable for regression (1) is the distance between the places of enlistment and of residence in 1880.

The dependent variables for logistic regressions (2) to (4) have a val value of one if a veteran moved, and zero otherwise. 